\title{
THE EIGHTEENTH-CENTURY BACKGROUND OF JOHN MARSHALL'S CONSTITUTIONAL JURISPRUDENCE
}

\author{
William E. Nelson*†
}

Between John Marshall's appointment to the Supreme Court in 1801 and Andrew Jackson's inauguration as President in 1829, the Marshall Court declared one congressional act unconstitutional ${ }^{1}$ and invalidated state statutes in fourteen cases. ${ }^{2}$ Among these cases were many of Marshall's major judicial opinions, including Marbury $v$. Madison, ${ }^{3}$ Fletcher v. Peck, ${ }^{4}$ McCulloch v. Maryland, ${ }^{5}$ Trustees of Dartmouth College v. Woodward, ${ }^{6}$ and Gibbons v. Ogden. ${ }^{7}$

Marshall's constitutional cases have been of enduring significance and have generated widespread scholarly debate. Perhaps the single issue that has most divided scholars is whether the great Chief Justice should be understood to have been motivated primarily by political considerations or by more neutral principles that were less political in character. On the one hand, many scholars have con-

* Associate Professor of Law, Yale Law School. A.B. 1962, Hamilton College; LL.B. 1965, New York University; Ph.D. 1971, Harvard University.-Ed.

$\dagger$ An earlier draft of this essay was delivered as the Thomas M. Cooley Lecture at The University of Michigan Law School on November 5, 1975. I am grateful to Dean Theodore J. St. Antoine and his colleagues for the opportunity to deliver that lecture. I am indebted to Bruce A. Ackerman, Robert A. Burt, Robert M. Cover, Owen M. Fiss, and Jerry L. Mashaw for their comments and criticisms, and to T. Alexander Aleinikoff and Adam J. Hirsch for their research assistance. This essay had its origin in conversation with George L. Haskins, to whom I am especially grateful, at a time when we were both working through the same material.

1. See Marbury v. Madison, 5 U.S. (1 Cranch) 137 (1803).

2. See Weston v. City Council, 27 U.S. (2 Pet.) 449 (1829); Brown v. Maryland, 25 U.S. (12 Wheat.) 419 (1827); Osborn v. President of the Bank, 22 U.S. (9 Wheat.) 738 (1824); Gibbons v. Ogden, 22 U.S. (9 Wheat.) 1 (1824); Green v. Biddle, 21 U.S. (8 Wheat.) 1 (1823); Farmers \& Merchanics' Bank v. Smith, 19 U.S. (6 Wheat.) 131 (1821); Trustees of Dartmouth College v. Woodward, 17 U.S. (4 Wheat.) 518 (1819); McCulloch v. Maryland, 17 U.S. (4 Wheat.) 316 (1819); McMillan v. McNeill, 17 U.S. (4 Wheat.) 209 (1819); Sturges v. Crowninshield, 17 U.S. (4 Wheat.) 122 (1819); Terret v. Taylor, 13 U.S. (9 Cranch) 43 (1815) (dictum); New Jersey v. Wilson, 11 U.S. (7 Cranch) 164 (1812); Fletcher v. Peck, 10 U.S. (6 Cranch) 87 (1810); United States v. Peters, 9 U.S. (5 Cranch) 115 (1809).

3. 5 U.S. (1 Cranch) 137 (1803).

4. 10 U.S. (6 Cranch) 87 (1810).

5. 17 U.S. (4 Wheat.) 316 (1819).

6. 17 U.S. (4 Wheat.) 518 (1819).

7. 22 U.S. ( 9 Wheat.) 1 (1824). 
cluded, to quote one leading constitutional historian, that "[a]s a good Federalist, Chief Justice Marshall sought, naturally, to embody the point of view of his party . . . in constitutional law." 8 At the other extreme, there exists a body of scholarship that understands Marshall and his contemporaries to have "plant[ed] themselves upon the provisions of the written Constitution, and den[ied] to popular legislation the binding force of law, whenever such legislation infringe[d] a constitutional provision." 9

Most recent students of the Marshall Court have found this second view implausible. Well aware of the ambiguities inherent in written texts, these students have concluded that Marshall could not possibly have been guided by unambiguous, unchanging legal rules that pre-existed his decisions. Those who in recent years have emphasized nonpolitical elements in Marshall's constitutionalism have concentrated on the now neutral principles to which his decisions gave rise and have given scant attention to the sources from which those decisions were molded. ${ }^{10}$ In particular, they have not questioned the thesis that Marshall embroidered his Federalist political beliefs into constitutional doctrine. In this essay, I will question that thesis and will present an alternative suggesting that, even though there were no specific, pre-existing legal principles from which Marshall could have deduced his major constitutional decisions, his jurisprudence nonetheless had important roots of a nonpolitical sort.

We need a new thesis about the roots of Marshall's constitutionalism for two reasons. One is that students inclined to view Marshall as a neutral rather than a partisan judge should find it easier to do so if they can understand him to have been motivated by something other than the views of a single political group. More significantly, a new thesis is needed because the existing one, as I am about to show, does not fully explain the outcome of several of Marshall's cases.

Marshall, according to the received learning, consciously furthered the political goals of the Federalist Party, first, by stretching the Constitution's meaning to increase national power at the expense of state power, and, second, by designing constitutional doctrines

8. E. Corwin, Court over Constitution 98 (1938).

9. C. Tiedeman, The Unwritten Constitution of the United States 163 (1890). See also R. Berger, Congress v. The Supreme Court 335-36 (1969); T. Cooley, A Treatise on the Constitutional Limitations 237-38 (7th ed. 1903); 1 W. Crosskey, Politics AND THE CONSTITUTION 50-192 (1953).

10. See A. Bickel, The Least Dangerous Branch 1-14, 23-28 (1963); H. Hart \& H. Wechsler, The Federal Courts and the Federal System 92-93 (1953); T. Powell, VAGARIES AND VARIETIES IN CONSTITUTIONAL INTERPRETATION 12-23 (1956). For similar views of an earlier scholar, see J. Thayer, John Marshall 58-59, 77-78, 84 (1901). 
that protected the upper classes' privileges against the growing democratic onslaught that in 1829 finally placed Andrew Jackson in the White House. Many scholars have emphasized Marshall's nationalism. Nearly sixty years ago, for instance, Charles Warren wrote of "Marshall's broad constitutional views" on the scope of national power." ${ }^{11}$ Fifteen years later Felix Frankfurter contended that "Valley Forge made" Marshall "a nationalist" and that "ties of friendship and shared labors in the struggle for the Constitution confirmed his faith." 12 Frankfurter continued that "the deepest article" of Marshall's "faith" as a judge was "[t]he need of a strong central government," not because the Constitution requires it but because, as Frankfurter suggested, Marshall believed such a government would become "the indispensable bulwark of the solid elements of the nation."13 Similarly, Marshall's biographer, Albert Beveridge, found that "Marshall unhesitatingly struck down State laws and shackled State authority" and "just as firmly and promptly upheld National laws and National authority." 14 Marshall upheld federal law, said Beveridge, "even when he believed the law before him to be unwise in itself, injurious to the Nation, and, indeed, of extremely doubtful constitutionality," for "[t]he purpose of his life was to strengthen and enlarge the powers of the National Government." 15 In becoming "the constructing architect of American Nationalism,"16 Marshall "rewrote the fundamental law of the Nation."17

Upon more careful examination, however, it appears that Marshall's nationalism was more limited in scope than the received learning suggests. Perhaps the Marshall Court was aggressively nationalistic in McCulloch v. Maryland, ${ }^{18}$ but it was not nationalistic at all in United States v. Hudson \& Goodwin ${ }^{19}$ nor in Wilson v. Black Bird Creek Marsh Co. ${ }^{20}$ In Hudson \& Goodwin, Marshall joined in an opinion rejecting the old and important Federalist plank ${ }^{21}$ that

11. 1 C. Warren, The Supreme Court in United States History 503-04 (1922).

12. F. Frankfurter, The Commerce Clause Under Marshall, Taney and Waite 14 (1937).

13. Id.

14. 4 A. Beveridge, The Life of John Marshall 117 (1919).

15. Id.

16. Id. at 169 .

17. Id. at 308. See also R. Ellis, The Jeffersonian Crisis 55 (1971); C. Haines, The Role of the Supreme Court in AMerican Government and Politics 1789-1835, at 619 (1944).

18. 17 U.S. (4 Wheat.) 316 (1819).

19. 11 U.S. (7 Cranch) 32 (1812).

20. 27 U.S. (2 Pet.) 245 (1829).

21. See J. SMith, Freedom's Fetters 131-33 (1956). 
federal courts had jurisdiction to try common-law crimes. ${ }^{22}$ In Black Bird Creek, Marshall refused to hold that national power to regulate interstate commerce superseded state regulation where Congress had not legislated pursuant to that power. ${ }^{23}$ Although the Marshall Court may have exhibited more nationalism in McCulloch than many Americans would have desired, it displayed less in Hudson \& Goodwin and Black Bird Creek.

Marshall in other cases did manifest two limited allegiances to nationalism, but neither of them was especially political. In United States v. Peters ${ }^{24}$ and Martin v. Hunter's Lessee, ${ }^{25}$ the Marshall Court posited that state authority could not prevent the execution of a federal court judgment, and in McCulloch v. Maryland ${ }^{26}$ and Gibbons $v$. Ogden ${ }^{27}$ it insisted that any state law inconsistent with the Constitution or an act of Congress was void. But, although these views were not uncontroversial in Marshall's time, they also were not "broad constitutional views" 28 of an "ardent nationalist." 29 The Supremacy Clause ${ }^{30}$ and the Judiciary Act of $1789^{31}$ mandated the supremacy of federal law over conflicting state law and the enforceability of federal court judgments as clearly as any legal text requires a specific result. Marshall or any other Chief Justice could hardly have proclaimed opposite views, and important representatives of both political parties, including sitting Presidents such as James Madison, ${ }^{32}$ concurred. These nationalistic opinions were less expressions of the Federalist program than essential provisions for an effective federal government.

Moreover, these two narrow aspects of Marshall's nationalism fail to account for much of his constitutional jurisprudence. They do not explain, for example, why Marshall read the contract clause as he did in Fletcher and in Dartmouth College, or why he so broadly construed the legislative power of Congress in McCulloch and Gibbons. A brand of nationalism capable of determining the results of these four cases would have had to comprehend much

22. 11 U.S. (7 Cranch) at 34.

23. 27 U.S. (2 Pet.) at 251-52.

24. 9 U.S. (5 Cranch) 115 (1809).

25. 14 U.S. (1 Wheat.) 304 (1816)

26. 17 U.S. (4 Wheat.) 316 (1819).

27. 22 U.S. (9 Wheat.) 1 (1824).

28. 1 C. WARREN, supra note 11 , at 503-04.

29. R. Ellis, supra note 17, at 55.

30. U.S. Const. art. VI, § 2.

31. Ch. 20, § 34, 1 Stat. 73 (1789).

32. See text at note 181 infra. 
more than the supremacy of federal law and the enforceability of federal court judgments. A narrow reading of Marshall's nationalism, in short, fails to account for the breadth of some of his decisions, while a broad reading does not explain the limitations imposed by cases like Hudson \& Goodwin and Black Bird Creek.

Marshall is also said to have advanced Federalist objectives through concern "for the protection of the interests of the propertied." 33 Upon his death, the New York Evening Post accused Marshall of adhering to "political doctrines . . . of the ultra federal or aristocratic kind," saying that he "distrusted the virtue and intelligence of the people" and had "been, all his life long, a stumbling block . . . in the way of democratic principles." 34 Historians have agreed that Marshall distrusted democracy and advanced the interests of aristocrats. Beveridge concluded that Marshall's disposition of Fletcher v. Peck ${ }^{35}$ "increased the confidence in him of the conservative elements" and "gave steadiness to commercial intercourse at a time when it was sadly needed." 36 Charles Haines found Marshall's decisions, particularly Dartmouth College, designed to secure "the victory of those who sought to entrench special privileges." 37 Morton Horwitz articulated essentially the same position in a recent lecture which interpreted Marshall's constitutional jurisprudence as a bulwark against democratic, legislative redistributions of wealth. ${ }^{38}$

Like interpreting Marshall as a politically motivated nationalist, interpreting him as an agent of "conservative elements" 39 fails to reconcile the Marshall Court's decisions, or even all the language in Marshall's own opinions. A line of cases from Sturges $v$. Crowninshield ${ }^{40}$ in 1819 to Ogden v. Saunders ${ }^{41}$ in 1827 undermines this interpretation. Those cases tested the power of state legislatures to pass insolvency laws which hindered creditors in the collection of debts. Were Marshall seeking to entrench special privilege or to prevent legislative redistributions of wealth, one would expect him to condemn as broadly as possible all such state laws. Indeed, some scholars have concluded that Marshall sought to do precisely that in

33. B. Wright, The Growth of American Constitutional Law 43 (1942).

34. Quoted in 4 A. BEVERIDGE, supra note 14, at 591.

35. 10 U.S. (6 Cranch) 87 (1810).

36. 3 A. BEVERIDGE, supra note 14, at 594.

37. C. HaINes, supra note 17 , at 419.

38. Thomas M. Cooley Lecture delivered by Morton J. Horwitz at The University of Michigan Law School (Nov. 4, 1975).

39. 3 A. BEVERIDGE, supra note 14 , at 594.

40. 17 U.S. (4 Wheat.) 122 (1819).

41. 25 U.S. (12 Wheat.) 213 (1827) 
Sturges and Ogden. ${ }^{42}$ But those cases are more ambiguous. In an opinion by Marshall, the Court rejected an argument in Sturges that would have won a full and immediate victory for creditors: that Congress's power to enact bankruptcy legislation preempted and thereby voided all state bankruptcy or insolvency laws. Instead, Marshall more narrowly ruled that the contract clause only invalidated state legislation which impaired the obligation of contracts made before the legislation was enacted. ${ }^{43}$

Later cases ruled that a statute of one state does not affect the obligation of a contract made in another state either before or after the statute, ${ }^{44}$ but until Ogden $v$. Saunders,${ }^{45}$ the Court never squarely considered whether a state statute could impair the obligation of a contract made in the same state after the statute's enactment. A New York statute, which had been passed before the contract in question had been made in New York, discharged insolvent debtors who complied with its provisions. Writing in dissent, Marshall concluded that the statute was unconstitutional because it sought, by destroying the underlying obligation of the contract, to prevent all courts, including the Louisiana court in which suit had been commenced, from enforcing that contract. But he still refused to proclaim as broad a pro-creditor rule as he might have. Although the New York legislature could not destroy substantive contract rights and thereby prevent their enforcement in a federal court or in a court of another state, it could, Marshall observed, deprive creditors of all remedies in New York courts for the enforcement of those rights. Thus, in Ogden as in earlier cases, Marshall did not seize the most extreme pro-creditor position available but proceeded in a narrow, guarded way that cannot be explained by a unidimensional thesis that he served "the interests of the propertied." 46

Indeed, the most salient fact about Marshall's constitutional jurisprudence is that his decisions were produced by diverse forces tugging in often conflicting directions. As we have seen, Marshall was not a consistent nationalist. He took a pro-nationalist stance in McCulloch but then assumed an anti-nationalist stance in Hudson \& Goodwin and in Black Bird Creek. Similarly, his defense of privi-

42. See C. Haines, supra note 17 , at 626 ; B. Wright, The Contract Clause of the Constitution 28-29 (1938); Morton J. Horwitz, supra note 38.

43. 17 U.S. (4 Wheat.) at 196-97.

44. See McMillan v. McNeill, 17 U.S. (4 Wheat.) 209, 213 (1819); cf. Farmers \& Mechanics' Bank v. Smith, 19 U.S. (6 Wheat.) 131 (1821) (a state statute may not impair contract obligations previously made in the same state).

45. 25 U.S. (12 Wheat.) 213 (1827).

46. B. WRIGHT, supra note 33 , at 431 . 
lege in cases like Sturges and Ogden was moderate, not extreme. This inconsistency and moderation cannot be explained by analyzing only those putative forces-Marshall's Federalist principles - that point in a single direction.

Felix Frankfurter attempted to resolve this problem of explanation in The Commerce Clause Under Marshall, Taney and Waite. Frankfurter, whose book has for four decades profoundly influenced scholarship, did not deny that Marshall sought to embody Federalist principles in constitutional law. Instead, Frankfurter perceived a more complex, sophisticated process in which Marshall balanced those principles against other considerations. Thus he wrote that while Marshall

had rooted principles, he was pragmatic in their application. No less characteristic than the realization of the opportunities presented by the commerce clause to restrain local legislatures from hampering the free play of commerce among the states, was his empiricism in not tying the Court to rigid formulas for accomplishing such restrictions. His mind carried a hardheaded appreciation of the complexities of government, particularly in a federal system. Experience of men and affairs in the Virginia House of Burgesses, in Congress, as a diplomat, and as Secretary of State had reinforced a temperament to which abstract theorizing was never congenial, howsoever abstract the language in which he couched concrete results. ${ }^{47}$

Taking their cue from Frankfurter, other scholars have similarly explained how Marshall's Federalist principles were tempered by factors such as his "rhetorical skill." 48

For one who, like Frankfurter, believes that law embodies judges' political views, such a portrait of Marshall illustrates how judges should temper their inevitable political tendencies. I suspect that this portrait has helped stimulate scholars such as Alexander Bickel, Henry Hart, and Herbert Wechsler to develop their subtle prescriptions for judicial restraint. But, however usefully such a view of Marshall stimulates theorizing about how judges ought to behave, it cannot explain with any precision how Marshall in fact behaved. Historians, for example, cannot accurately describe Marshall as an adherent of Bickel's "passive virtues," since many of those virtues were not yet developed in Marshall's time. Although Marshall's motivations may have been similar to those prescribed by modern legal process theorists, they were not identical, and thus interpretations of his jurisprudence that rely on those modern theories may be seriously imprecise. Vague and general words like "rhetori-

47. F. FRANKFURTER, supra note 12, at 14-15.

48. R. Faulkner, The Jurisprudence of John Marshall 212 (1968). 
cal skill" 49 and "empiricism" 50 in lieu of specific descriptions of countervailing considerations to Marshall's Federalist principles are similarly flawed.

Interpreting Marshall's constitutional jurisprudence as "embodying his political and economic views" or those of the Federalist Party ${ }^{51}$ is not just imprecise. All such explanations are problematic for at least three other reasons. First, they do not explain how Marshall dominated his Republican colleagues, who after 1811 constituted a majority of the Court. Saying that Marshall somehow "Federalized" those Republicans through his "steady and directing influence" 52 hypothesizes much but, as Marshall himself noted, 53 explains little. Second, political interpretations of Marshall's jurisprudence have tended to view Federalism as a monolithic economic and political ideology, but recent scholarship suggests that the party was riven by ideological differences. ${ }^{54}$ Third, the political explanation ignores early nineteenth-century constitutional doctrines quite similar to Marshall's elaborated by lower federal and state court judges, not all of whom were Federalists and few of whom were as pragmatic and skillful as Marshall.

Hence, further analysis of the background of Marshall's constitutional jurisprudence is not inappropriate. I will offer in this essay an interpretation claiming that Marshall, who was born in Virginia in 1755 , did not seek to promote the policies of a single political group ${ }^{55}$ but attempted instead to preserve, albeit in a limited way, fragile mid-eighteenth-century processes of government by consensus. ${ }^{56}$ The essay will further suggest that once Marshall's objective

49. Id.

50. F. Frankfurter, supra note 12 , at 14.

51. C. HAINES, supra note 17 , at 83 .

52. Id. at 331, 333.

53. See John Marshall's Defense of McCulloch v. Maryland 81-82 (G. Gunther ed. 1969).

54. See M. Dauer, The Adams Federalists (1953).

55. On Marshall's apolitical character, see his statement to Joseph Story that he did not vote in national elections during two of his three decades on the bench. Letter from J. Marshall to J. Story (May 1, 1828), in 14 Proceedings of the Massachusetts Historical SocIETY 335, 336 (2d ser. 1900). In the same letter, Marshall commented, "[I]ntemperate [political] language ... [ [did] not become my age or office, and . . . [was] foreign from my disposition or habits." Id.

56. I do not mean to contend that the mid-eighteenth-century style of consensus government was the sole root of Marshall's constitutional jurisprudence. Another source of eighteenth-century values was the natural law-natural rights ideology of that era. For a recent analysis of that ideology, $\rightarrow$ Grey, Origins of the Unwritten Constitution: Fundamental Law in American Revolutionary Thought, 30 STAN. L. REV. 843 (1978). It seems likely that natural law and natural rights ideas gained their force by virtue of their widespread acceptability; those ideas may well have been part of a broader eighteenth-century consensus embracing other 
of consensus building became clear, men of nearly all political stripes at both federal and state levels could and did join in it.

To explain how Marshall used eighteenth-century political methods to resolve nineteenth-century problems, Part I of this essay analyzes the workings of the main institution of eighteenth-century government: the courts. ${ }^{57}$ That analysis suggests that mid-eighteenth-century government officials and lawyers encountered daily a style of governance which resolved disputes and other problems, not according to the particular policy preferred by those in power, but according to a widely shared consensus of values with which they addressed many though not all the issues brought before them. That eighteenth-century lawyers and officials did look to those consensual values meant that the government decided many questions independently of any single individual's or interest group's will. Social change may have been always threatening to dissolve whatever consensus existed, but, as Part I attempts to show, the power of eighteenth-century juries to determine law evidences the endurance of at least some degree of consensus.

Part II reviews the emergence in the last decades of the eighteenth century of national political divisions which culminated in the hotly contested presidential election of 1800 . This division brought to the fore an alternative governmental style in which a majority of the people self-consciously selected from among competing policies those that they wished government to effectuate.

Thus, John Marshall and his contemporaries faced a fundamental question in the first years of the nineteenth century: should the majority's will or should shared values which transcended that will guide American government? Part III of this essay argues that Marshall sought to accord both styles of government a place in the American polity. Marshall proposed that the courts have final authority to determine legal questions in a legal manner, that is, that nineteenth-century courts, like eighteenth-century courts, resolve by appealing to widely shared values those questions susceptible of such resolution. On the other hand, Marshall deferred political questions - those which shared values could not answer-to the major-

values as well. The relationship between natural law and natural rights ideas, on one hand, and whatever sorts of consensus that existed, on the other, is surely sufficiently complex to merit full analysis in another essay. I have not systematically pursued an analysis of natural law as a source of Marshall's jurisprudence, since I find the same difficulties in deriving constitutional rules from natural law that $I$ find in deriving them from the constitutional text. See text at notes 9-10 supra.

57. The evidence in Part $I$ is derived not only from Marshall's home state of Virginia. Since the essay is concerned with Marshall's contemporaries as well as with Marshall himself, data from other states, especially the three largest-Massachusetts, New York, and Pennsylvania—are also considered. 
ity's will as expressed through the politically oriented legislative and executive branches.

This analysis of Marshall's constitutional jurisprudence avoids the pitfalls of previous theories. It does not see the Federalist political program as the source of Marshall's constitutional doctrines and thus does not need to explain how Marshall qualified his political principles or how he convinced non-Federalist judges to accept them. Instead, this essay argues that legal, not political, principles underlay Marshall's jurisprudence, but it attempts to understand those principles in a manner consistent with the unavoidable twentieth-century assumption that law is a body of flexible rules responsive to social reality rather than a series of immutable, unambiguous doctrines derived from a nonhuman source. The essay briefly concludes by returning to the previous interpretations of Marshall's constitutional jurisprudence to compare the merits of those interpretations with this essay's new interpretation.

\section{Government by Consensus in Mid-Eighteenth-Century AMERICA}

\section{A. The Pervasive and Undifferentiated Role of Colonial Courts}

Courts were vital to mid-eighteenth-century colonial government, for that government, unlike our own, had no ubiquitous bureaucracy with clear chains of command reaching upward to central political authorities. Because there was no modern bureaucracy, the judiciary and the officials responsible to it (e.g., sheriffs), were the primary link between a colony's central government and its outlying localities. ${ }^{58}$ The judiciary alone could coerce individuals by punishing crimes and imposing money judgments. In some colonies, such as Virginia, the judiciary was virtually the whole of local government, ${ }^{59}$ but even in colonies where other officials were available, the nonexistence of doctrines of official immunity rendered those officials subject to judicial control. ${ }^{60}$ As one of Marshall's contemporaries observed, "[o]ther departments of the Government" may have been "more splendid," but only the "courts of justice [came] home to every man's habitation . . . ." 61

58. See P. Bonomi, A Factious People 145, 227 (1971); W. Nelson, Americanization of the Common Law 13-17 (1975); C. Sydnor, Gentlemen Freeholders 83-84, 86-93 (1952); C. Sydnor, Political Leadership in Eighteenth-Century Virginia 8 (1951).

59. See C. Sydnor, Gentlemen Freeholders, supra note 58, at 83-84, 86-93; C. SydNOR, POLITICAL LEADERSHIP, supra note 58, at 8.

60. See W. Nelson, supra note 58, at 17-18.

61. 18 ANNAls of CoNG. 110 (1802) (remarks of Sen. Hillhouse). 
The vital role of the courts in colonial government did not, however, mean that government performed only functions which we today would classify as judicial. Colonial government regulated its subjects' lives in pervasive detail; government in the Age of Mercantilism sought to insure not only the physical and economic, but the moral and social well-being of its subjects as well. ${ }^{62}$ The courts, as a vital part of the government, maintained order, protected life and property, apportioned and collected taxes, supervised the construction and maintenance of highways, issued licenses, and regulated licensees' businesses. ${ }^{63}$ Through administration of the Settlement Law, which permitted localities to exclude undesired newcomers, and the Poor Law, which made localities liable for the support and hence the general well-being of all who were born and raised in a locality and all newcomers who were not excluded, the legal system fostered community self-definition and a sense of community responsibility for inhabitants. ${ }^{64}$ Indeed, in some colonies, the courts of general sessions of the peace, which possessed basic criminal, administrative, and some minor forms of civil jurisdiction, also performed the executive and even the legislative functions of local government. ${ }^{65}$

The work of the courts, in sum, was of an undifferentiated, pervasive character. The undifferentiated character of that work was important for present purposes because it obscured distinctions between legislation, administration, and adjudication drawn by political theorists. Despite Montesquieu's early statement of the mod-

62. For example, Parliament passed the Navigation Acts to increase the wealth of the entire empire, see generally O. Dickerson, The Navigation ACTS AND the American Revolution (1951); L. Harper, The ENGlish Navigation Laws (1939), and colonial legislatures passed inspection acts to promote the sale of colonial products abroad, see J. GoEBEL \& T. Naughton, Law Enforcement in Colonial New York 41 n.201 (1944); O. Handlin \& M. Handlin, Commonwealth 64-65 (rev. ed. 1969). Nine of the thirteen colonies established state religions and all the colonies prosecuted immorality in such varying forms as fornication, drunkenness, profanity, and desecration of the Sabbath. See J. Goebel \& T. Naughton, supra, at 39-40, 100-06; W. Nelson, supra note 58, at 36-40; A. SCOTT, CRIMINAl LAW IN Colonial Virginia 280-81, 291-92 (1930); R. Semmes, Crime and Punishment in Early MARYLAND 148-49, 161-65 (1938); Flaherty, Law and the Enforcement of Morals in Early America, in 5 Perspectives in AMERICAN History 212-24 (1971).

63. See P. Bonomi, supra note 58, at 36 n.27; R. Ireland, The County Courts in ANtebellum KentuCKy 18-31 (1972); W. Nelson, supra note 58, at 15; C. Sydnor, AmeriCAN Revolutionaries in the Making 80-85 (1965).

64. See M. Creech, Three Centuries of Poor Law Administration 8-75 (1936); J. Henton, Warning Out in New England 9, 118-21 (1911).

65. See R. IReland, supra note 63, at 18; W. Nelson, supra note 58, at 15; C. Sydnor, supra note 63, at 80; Bockelman, Local Government in Colonial Pennsylvania, in Town AND County 216, 216-21 (B. Daniels ed. 1978); Carr, The Foundations of Social Order: Local Government in Colonial Maryland, in Town AND CounTy 72, 91-93 (B. Daniels ed. 1978). Local courts had fewer powers, however, in New York and South Carolina. See P. Bonomi, supra note 58, at 35-36; M. Sirmans, Colonial South Carolina 250-252 (1966). 
ern doctrine of separation of powers, ${ }^{66}$ Americans as late as the 1780 s generally regarded the courts as part of the executive and did not routinely distinguish the judiciary as an independent branch which exercised only "judicial" functions: they did not, that is, distinguish law from politics. As one tract observed,

Government is generally distinguished into three parts, Executive, Legislative and Judicial, but this is more a distinction of words than things. . . . [H] owever we may refine and define, there is no more than two powers in any government, viz, the power to make laws, and the power to execute them; for the judicial power is only a branch of the executive, the CHIEF of every country being the first magistrate. ${ }^{67}$

The pervasive character of the courts' work was important because it placed the courts, which are today at the periphery of governmental activity, at the core instead. It insured that men like John Marshall who learned the ways of government in the Revolutionary era would be familiar with the manner in which courts functioned. And it requires, if we are to understand the background and training of Marshall's generation, that we too study the workings of mideighteenth-century courts and of their most important agency, the jury.

\section{B. The Law-finding Power of Juries}

Although judges with the multifarious duties of mid-eighteenthcentury courts were prominent local leaders, they were leaders who had power only to guide, not to command. For juries rather than judges spoke the last word on law enforcement in nearly all, if not all, of the eighteenth-century American colonies. Except in equitable actions, which were nonexistent in some colonies and narrowly limited in the rest, ${ }^{68}$ judges could not enter a judgment or impose a penalty without a jury verdict. ${ }^{69}$ And, in the cases in which they sat,

66. For a discussion of Montesquieu, see M. Vile, Constitutionalism AND the SeParaTION OF POWERS 76-97 (1967).

67. Four Letters on Interesting Subjects 21 (Philadelphia 1776). For other similar statements, see M. VILE, supra note 66 , at 139 . This merely reflected older views. For example, Thomas Hutchinson, the pre-Revolutionary chief justice and governor of Massachusetts, spoke of courts as part of "the Executive Body" and possessors of "Executive" as distinguished from "Legislative" power. Charge to the Grand Jury, Quincy 307 (Mass. 1769). John Adams similarly regarded "the first grand division of constitutional powers" as "those of legislation and those of execution," with "the administration of justice" resting in "the executive part of the constitution." J. ADAMs, The Earl of Clarendom to William Pym in 3 THE Works of JoHN ADAMS 480-82 (C. Adams ed. 1851). Although Adams drafted most of the Massachusetts Constitution of 1780 , he did not draft its famous separation of powers clause. See M. VILE, supra note 66, at 149.

68. See Katz, The Politics of Law in Colonial America, in 5 Perspectives IN AMERICAN HisTORY 257, 262-65 (1971).

69. See W. Nelson, supra note 58 , at 21 . 
eighteenth-century juries, unlike juries today, usually possessed the power to determine both law and fact.

Although the common law of eighteenth-century England recognized several devices for controlling jury findings of law and fact, mid-eighteenth-century American courts appear not to have used them extensively in either civil or criminal cases. One device apparently in use in England was special pleading and the exclusion from evidence of all matters immaterial to the special plea. Special pleading had the capacity of framing a single, simple factual question for the jury which the jury could decide without passing upon the law, since the court's prior determination of the legal sufficiency of proffered pleas resolved all questions of law before a case was given to the jury. ${ }^{70}$ But there is no evidence that special pleading was widely used in colonial America, except perhaps in early eighteenth-century Maryland. ${ }^{71}$ Litigants usually preferred to try cases not under a special plea, but under a plea of the general issue, so called because it imported an absolute and general denial of every allegation and put all the allegations in issue before the jury. When the general issue was pleaded, juries did not confront only evidence directly relevant to a single issue, but instead heard evidence on several issues and during deliberation had to decide how those issues related to each other. ${ }^{72}$ Thus, jurors found not only facts but also the legal conse-

70. Id. at 21-22 and sources cited therein.

71. Litigants in Massachusetts rarely continued special pleading beyond defendant's initial plea and the plaintiff's joinder of issue or joinder in demurrer, see id. at 23 , and the published colonial cases suggest that special pleading was also rare in Pennsylvania and Virginia. The only special pleading case reported in pre-Revolutionary Pennsylvania, Swift v. Hawkins, 1 Dall. 17 (Pa. 1768), involved merely a joinder of issue to a plea of payment in a writ of debt. No cases of special pleading are recorded in REPORTS OF CASES DETERMINED IN THE GENERAL COURT OF VIRGINIA FROM 1730 TO 1740; AND FROM 1768 To 1772 (T. Jefferson ed. 1829), the only volume of pre-Revolutionary Virginia cases. Special pleading may have been common in Maryland from about 1710 to 1730 , since it occurred in seven out of twenty-one reported cases. See Brooke v. Macnemara, 1 H. \& McH. 80 (Md. Provincial Ct. 1728); Lord Proprietary v. Gibbs, 1 H. \& McH. 58 (Md. Provincial Ct. 1723); Lord Proprietary v. Wright, 1 H. \& McH. 49 (Md. Provincial Ct. 1722); Hemsley v. Smith, 1 H. \& McH. 42 (Md. Provincial Ct. 1720); Lord Proprietary v. Cockshut, 1 H. \& McH. 40 (Md. Provincial Ct. 1720); Gresham v. Gassaway, 1 H. \& McH. 34 (Md. Provincial Ct. 1718); Tanner v. Freeland, 1 H. \& McH. 34 (Md. Provincial Ct. 1718). But special pleading appears to have been less common thereafter, occuring in only four of eighty-six non-chancery cases reported between 1730 and 1774. See Coursey v. Wright, 1 H. \& McH. 394 (Md. Provincial Ct. 1771); Lord Proprietary v. Bond, 1 H. \& McH. 210 (Md. Provincial Ct. 1760); Hammond v. Denton, 1 H. \& McH. 200 (Md. Provincial Ct. 1755); Lewis v. Cooke, 1 H. \& McH. 159 (Md. Provincial Ct. 1749).

72. A plea of the general issue did not frame a single, precise factual question for two reasons. First, a typical complaint alleged several facts, all of which a general denial put in issue. Second, courts did not restrict the parties (as they did in the case of a special plea) to proof only of facts tending to verify their allegations. The test of admissibility of evidence under the general issue was not relevance to a single factual question, but whether as a matter of law the proposed evidence ought to constitute a good defense to the plaintiff's action. W. Nelson, supra note 58, at 22-23. Thus, the court might permit a defendant to present to the 
quences of facts; that is, absent other restrictions they decided the law. The result was that, although special pleading had the potential to reduce the power of juries to determine law as well as fact, its disuse in colonial America prevented it from attaining that potential.

A second common-law device to control juries' findings of law was the special verdict, by which a jury merely stated its factual conclusions without expressing any opinion about which party should win. The court then applied the law to the facts and rendered judgment. This procedure was not especially effective in controlling the law-finding powers of colonial American juries, however, since all the litigants had to agree to it. Any party could as a matter of right demand a general verdict in which the jury applied the law to the facts. ${ }^{73}$ When it was used, counsel on both sides would usually draft notes for the verdict which the jury then rendered; but even then the verdict could be entered on the record only if objections by counsel for both litigants were resolved to their mutual satisfaction. Litigants probably used special verdicts chiefly in complex factual cases where both sides were at least as interested in a judicial declaration of law for their future guidance as in a resolution of the pending dispute. ${ }^{74}$ In typical cases, especially if one of the parties anticipated that the jury would render a favorable general verdict, special verdicts were rare.

Furthermore, it was not clear that an unwilling jury could be forced to return a special verdict even if both parties desired one. John Adams, for instance, denied that juries were "under any legal or moral or divine Obligation to find a Special Verdict where they themselves are in no doubt of the Law." 75 The Maryland Provincial Court apparently shared that view, for after the jury in Smith's Lessee v. Broughton ${ }^{76}$ returned a general verdict in favor of the de-

jury not only evidence relating to facts raised by the plaintiff (e.g., evidence of performance in an action of assumpsit), but evidence of other facts as well. Indeed, by the outbreak of the American Revolution, the courts of Massachusetts, see id. at 23; Maryland, see Drane v. Hodges, 1 H. \& McH. 518 (Md. 1773); and perhaps other colonies were even allowing defendants to put in evidence under the general issue matters which under strict common-law rules had to be pleaded specially.

73. See generally Henderson, The Background of the Seventh Amendment, 80 HARv. L. Rev. 289, 307-10 (1966); Wroth \& Zobel, Introduction to 1 LeGAl PAPERs of JoHN ADAMS at xlvii (L. Wroth \& H. Zobel eds. 1965).

74. This is at least my sense after an extensive, albeit unsystematic, search of Massachusetts court records from the mid-eighteenth century.

75. 1 Legal Papers of John Adams 230 (L. Wroth \& H. Zobel eds. 1965).

76. 1 H. \& McH. 33 (Md. Provincial Ct. 1714). As recorded, the disposition of the case is ambiguous and subject to misinterpretation if read in isolation. Because the final entry in Broughton is "[j]udgment on the verdict of nonsuit," the case has been read to grant a compulsory nonsuit "by implication." Henderson, supra note 73, at 301 n.25. In fact, this literal reading of the entry is impossible: the verdict in Broughton was for the defendant, the plaintiff was 
fendant even though the court, with both parties' consent, had instructed it to find a special verdict, the Maryland court rejected the plaintiff's argument that the jury's disobedience warranted an arrest of judgment. ${ }^{77}$

Some scholars believe that the demurrer to the evidence and the compulsory nonsuit, somewhat similar and overlapping procedures, were also available to prevent juries from applying law to facts. ${ }^{78}$ Although either party could claim through a demurrer to the evidence that his opponent's evidence was insufficient to support an allegation, it appears that defendants demurred more commonly than plaintiffs, often claiming at the close of a plaintiff's affirmative case that the evidence did not support the cause of action. ${ }^{79}$ When such

the moving party, and a plaintiff could not nonsuit himself. See note 79 infra. As the entry immediately followed the recording of the motion in arrest of judgment, and as a nonsuit normally did not constitute a final judgment but permitted a plaintiff to seek a new trial, the use of the expression might alternatively be construed as a rejection of the jury's perverse verdict and permission for the plaintiff to seek a new trial. However, when the ambiguous text is compared with other cases in the volume of reports edited by Harris and McHenry, it becomes apparent that the courts sporadically used the term "nonsuit" in this context to indicate a final judgment for the defendant rather than a trial de novo. We find entries roughly equivalent to Broughton's on two other occasions in the volume: "Verdict for the defendant, and judgment of nonsuit." Carroll's Lessee v. Llewellin, 1 H. \& McH. 162, 168 (Md. Provincial Ct. 1750); Black v. Digge's Exrs., 1 H. \& McH. 153, 153 (Md. Provincial Ct. 1744). We may infer with confidence that "judgment of nonsuit" in these cases translates into "judgment for defendant" and not trial de novo because (1) technical nonsuits were impossible since the verdicts were for defendant; (2) the verdicts in both cases accorded with the courts' instructions and hence were not potentially vitiable as verdicts "against law," see text at note 106 infra; and especially (3) the plaintiffs appealed both judgments. Thus the phrase "[j]udgment on the verdict of nonsuit" in Broughton probably indicates the entry of judgment for defendant, as dictated by the verdict, despite the plaintiff's motion in arrest of judgment on the ground that the jury's general verdict violated the agreement of the parties. An evaluation of the case found in the index to the volume further confirms this conclusion. See 1 H. \& McH. at 596.

77. For a New York case in which a jury returned a general verdict after the parties had agreed on a special one, see Brown v. Clock (N.Y. Sup. Ct. 1695), reprinted in Collections of THE New-York Historical SocietY FOR THE YeAR 1912, at 69-70 (1913). English authority existed for both the proposition that a jury could return a general verdict against the parties' agreement to accept a special one, and the contrary proposition that a general verdict rendered in those circumstances should be set aside. Compare Gay v. Cross, 7 Mod. 37, 87 Eng. Rep. 1078 (K.B. 1702); Anonymous, 3 Salk. 373, 91 Eng. Rep. 881 (K.B. 1697); 2 J. LiLly, THE Practical Register: Or, A General Abridgment of the Law 793 E (2d ed. 1735), with The King v. Poole, Cas. t. Hard. 23, 95 Eng. Rep. 15 (K.B. 1734); Pocklington v. Hatton, 8 Mod. 220, 88 Eng. Rep. 158 (K.B. 1724); Regina v. Ballivos de Bewdley, 1 P. Wms. 207, 24 Eng. Rep. 357 (Ch. 1712); 2 J. Lilly, supra, at 798 C. The English cases are discussed in Henderson, supra note 73, at 307-09.

78. See Henderson, supra note 73, at 300-01, 304-05.

79. Although a plaintiff could theoretically demur to a defendant's evidence, see Kissam v. Burrell, Kirby 326, 328 (Conn. Super. Ct. 1787); Smith v. Steinbach, 2 Cai. Cas. 158, 171 (N.Y. 1805); Lessee of the Proprietary v. Ralston, 1 Dall. 18, 18 (Pa. Sup. Ct. 1773), he rarely advanced his interest by doing so. Even if the court held the defendant's evidence objectionable, judgment could not be entered for the plaintiff since a defendant who did not concede the veracity of the plaintiff's evidence would normally still be entitled to his right to have the jury pass upon the truth of that evidence. Nor could a defendant, such as the royal customs collector in Erving v. Cradock, Quincy 553 (Mass. 1761), see text at note 105 infra, elect by way of demurrer to present an affirmative defense to the court rather than the jury, since only the 
demurrers were interposed, the judge, circumventing the jury, would rule on the legal sufficiency of the plaintiff's evidence. According to an early nineteenth-century case in South Carolina, the nonsuit similarly lay "wherever it appears that the evidence is insufficient to make out the plaintiff's case, or where there is a total failure of proof necessary for that purpose." 80 In such a case, a trial court was directed to grant a defense motion for nonsuit "whether the plaintiff consent or not."81

However, neither the compulsory nonsuit nor the demurrer to evidence effectively reined jury power in eighteenth-century America. Prior to 1800, published reports include no case in which the compulsory nonsuit was used to prevent a jury from determining an issue of law otherwise before it. ${ }^{82}$ The demurrer to evidence, though extant in five states, ${ }^{83}$ similarly failed to keep cases away from the jury

plaintiff could demur to the defendant's evidence and thereby take consideration of the evidence away from the jury; a defendant could not demur to his own evidence. And, as a doctrinal matter, of course, only a defendant could obtain a nonsuit in his favor. See Hopkins v. De Graffenreid, 2 S.C.L. (2 Bay) 441, 445 (1802); 5 M. BACON, A NEW ABridgMENT OF THE LAW 140-41 (1st American ed. from the 6th London ed. 1811); W. WyCHE, A Treatise on the Practice of the Supreme Court of Judicature of the State of New-York in Civil ACTIONS 167 (2d ed. New York 1794); Henderson, supra note 73, at 300-01.

80. Hopkins v. De Graffenreid, 2 S.C.L. (2 Bay) 441, 445 (1802).

81. Hopkins v. De Graffenreid, 2 S.C.L. (2 Bay) 441, 445 (1802). English authority existed for nonsuiting a plaintiff even after a jury had rendered a verdict in his favor if a nonsuit would have been appropriate prior to submission of the case to the jury. See, e.g., Abbot v. Plumbe, 1 Dougl. 216, 99 Eng. Rep. 141 (K.B. 1799); Bird v. Randall, 1 B1.W. 373, 96 Eng. Rep. 210 (K.B.), reargued, 1 B 1.W. 387, 96 Eng. Rep. 218 (K.B. 1762).

82. The only states in which nonsuit cases have been found are Maryland, New Jersey, New York, Pennsylvania and South Carolina. See Henderson, supra note 73, at 301. In Maryland, the earliest reported case occurred in 1802. See Webb's Lessee v. Beard, 1 H. \& J. 349 (Gen. Ct. 1802). In New Jersey, the earliest reported case occurred in 1807. See Pearson v. Hopkins, 2 N.J.L. 181 (Sup. Ct. 1807). In New York, the earliest reported case occurred in 1800. See Pratt v. Hull, 13 Johns. 334 (N.Y. Sup. Ct. 1816); Percival v. Jones, 2 Johns. Cas. 49 (N.Y. Sup. Ct. 1800). In South Carolina, the Superior Court claimed the right to order a nonsuit in a 1798 case and an 1802 case, although it did not exercise that right on either occasion. See Brown v. Frost, 2 S.C.L. (2 Bay) 125 (1798); Hopkins v. De Graffenreid, 2 S.C.L. (2 Bay) 441, 445 (1802). The court's statement on the latter occasion that nonsuits were "the invariable practice both before and since [1798]," 2 S.C.L. (2 Bay) at 445, should not be taken at face value, however. $C f$. W. NELSON, supra note 58, at 9-10 (courts purported to follow English law when in fact they did not). In Pennsylvania, the compulsory nonsuit was utilized in the 1790s, apparently to decide issues of pleading which could otherwise have been handled by a demurrer to the pleadings. See Mullen v. Ridgeway, Add. Pa. 278 (Fayette County Ct. 1795); Farnesly v. Murphy, Add. Pa. 22 (Allegheny County Ct. 1792). In the 1770 s, the nonsuit also served as a device by which a plaintiff could elect not to receive a verdict which he anticipated would be against him. See Anonymous, 1 Dall. 20 (Pa. 1773); Lessee of Richardson v. Campbell, 1 Dall. 10 (Pa. 1764). But see Lessee of the Proprietary v. Ralston, 1 Dall. 18 ( $\mathrm{Pa}$. 1773), a poorly reported case in which a motion for a nonsuit, the nature of which was unclear, was denied. I do not take the Maryland case of Smith's Lessee v. Broughton, 1 H. \& McH. 33 (Md. Provincial Ct. 1714), which has been read as a nonsuit case, see Henderson, supra note 73 , at 301 , to have been such. See note 76 supra.

83. Connecticut, Maryland, New York, Pennsylvania, and Virginia. Connecticut: Kissam v. Burrall, Kirby 326, 328 (Conn. Super. Ct. 1787). Maryland: Lord Proprietary v. Bond, 1 H. \& McH. 210, 210 (Md. Provincial Ct. 1760); Savory's Lessee v. Whayland, 1 H. \& McH. 206, 


\section{because procedural disadvantages discouraged its use. ${ }^{84}$}

Thus, due to the apparent infrequency of special pleading and the ineffectiveness of demurrers to the evidence and procedures for compulsory nonsuits and special verdicts, juries usually must have returned general verdicts in lawsuits not decided by default. In the absence of modern procedural devices such as judicial instructions on law and evidence and the practice of setting aside verdicts contrary to law or evidence, this meant that juries in both civil and criminal cases were usually called upon to find both law and fact. Although these modern devices were in use in England by the time of Bright v. Eynon ${ }^{85}$ and Appleton v. Sweetapple, ${ }^{86}$ neither device

206 (Md. Provincial Ct. 1755); Beale et Ux. Lessee v. Digges, 1 H. \& McH. 26, 27 (Md. Provincial Ct. 1705); Seward's Lessee v. Hicks, 1 H. \& McH. 22, 22 (Md. Provincial Ct. 1705). New York: Smith v. Steinbach, 2 Cai. Cas. 158, 158 (N.Y. 1805); Thurman v. Tucker (N.Y. Mayor's Ct. 1744), reprinted in American Historical Association, Select Cases of the Mayor's Court of New York CITY 1674-1784, at 155, 159 (R. Morris ed. 1935) [hereinafter cited as MAYOR's Court of New York CITY]; Fullerton v. Sincklair (N.Y. Sup. Ct. 1703), reprinted in 2 P. Hamlin \& C. Baker, Supreme Court of Judicature of the Province of New York 1691-1704, at 141, 142, 162 (1959) [hereinafter cited as P. HAMLIN \& C. BAKER]; Nightingall v. Lott, (N.Y. Sup. Ct. 1703), reprinted in P. HAMLIN \& C. BAKER, supra at 150, 151; Ewetse v. Rosavelt, (N.Y. Sup. Ct. 1703), reprinted in P. HAMLIN \& C. BAKER, supra at 153, 162, 218. Pennsylvania: Hurst v. Dippo, 1 Dall. 20, 21 (Pa. 1774); Lessee of the Proprietary v. Ralston, 1 Dall. 18, 18 (Pa. 1773). Virginia: Stephens v. White, 2 Va. (2 Wash.) 203, 203 (1796).

84. As the Pennsylvania Supreme Court implied in Hurst v. Dippo, 1 Dall. 20 (Pa. 1774), the demurrer to the evidence was "disused" in most colonies. The most severe disadvantage was that the demurrant had to admit all the facts shown in the evidence against him and all adverse inferences that could be drawn from those facts. See Thurman v. Tucker (N.Y. Mayor's Ct. 1744), reprinted in MAYOR's COURT OF New YORK CITY, supra note 83, at 155, 159. In addition, the demurrant lost his case when a demurrer to the evidence was overruled, but when a demurrer was sustained in a case that involved additional issues, the jury would still determine the merits of the case under instructions to ignore the objectionable evidence it had heard. For examples of two cases that were determined by a jury after at least one of the parties attempted to demur to the evidence, see Brown v. Clock (N.Y. Sup. Ct. 1695), reprinted in Collections of THE New-York Historical Society for the Year 1912, at 69-70 (1913); Lessee of the Proprietary v. Ralston, 1 Dall. 18 (Pa. 1773). Similarly, 3 G. GiLbert, THE LAw of Evidence 1214-15 (C. Lofft ed. 1797), suggests that a demurrer would not always take a case away from the jury.

Dippo itself illustrates yet another difficulty with the demurrer. The plaintiff claimed title to the land in dispute through an ancestor whose name was among the grantees on a list that bore the warrant, seal, and signature of William Penn. The defendant's demurrer essentially raised an issue of law-whether the list constituted a deed from Penn to the ancestor-yet the court refused to permit the demurrer and directed the jury "to draw their inference" about title to the land "from the evidence laid before them" and "the custom of the province, in the like cases." I Dall. at 21. (Apparently for decorum's sake, the court prefaced this ruling with the contradictory statement that "[i]t is a settled rule, that courts of law determine law; a jury facts." 1 Dall. at 21.) Although the Pennsylvania courts surely would have sustained a demurrer to the evidence if a plaintiff introduced evidence of an assumpsit to prove a trespass vi et armis, those courts at least seem to have been unprepared in less blatant cases to use that procedure to negate the jury's effective power to determine law and custom.

85. 1 Burr. 390, 2 Keny. 53, 96 Eng. Rep. 1104 (K.B. 1757). For the English practice on rejection of jury verdicts, see generally Henderson, supra note 73, at 311-12; Note on the Development of the Right to a New Trial in England (forthcoming in 3 HAMILTON LEGAL PAPERS (J. Goebel \& J. Smith eds. 1979)).

86. 3 Dougl. 137, 140-41, 99 Eng. Rep. 579, 580 (K.B. 1782). 
was an effective instrument for jury control in pre-Revolutionary America.

Instructions to the jury were ineffective for several reasons. First, it appears that in many cases instructions were brief and rudimentary. In Massachusetts, lawyers could and did assume that jurors were "good judges of the common law of the land," 87 since "[t]he general Rules of Law and common Regulations of Society, under which ordinary Transactions arrange[d] themselves, ... [were] well enough known to ordinary Jurors." 88 Accordingly juries might be directed that, as to many matters, they "need[ed] no Explanation [since] your Good Sence \& understanding will Direct ye as to them." 89 In Connecticut, the court merely summarized the opposing claims without commenting on the law involved in the case, ${ }^{90}$ while in New Hampshire one judge told a jury "to do justice between the parties not by any quirks of the law . . . but by common sense as between man and man."91 Likewise, in one criminal case in colonial New York, Chief Justice Mompesson informed the jury that "there are some points [of law] I am not now prepared to answer," 92 while in another case the court informed the jury only that the evidence from the prosecution's witnesses seemed "so ample, so full, so clear and satisfactory" that it should convict the prisoner "if you have no particular reasons in your own breast, in your own consciences to discredit them."93 Similarly, in South Carolina civil litigation in the 1780 s, one jury was instructed "to find a general verdict, or a special one, . . . as they thought proper,"94 while another jury was told "to give what they thought reasonable" in "damages." 95 In other cases, no instructions were given at all; in Virginia, for example, according to one commentator, there were "numerous cases" in which the jury "retired without a word said by the court upon the subject" of the case. 96

87. Letter from James Sullivan to Elbridge Gerry (Dec. 25, 1779) (unpublished letter, Massachusetts Historical Society), quoted in W. NelsoN, supra note 58, at 26.

88. I Legal Papers of John Adams, supra note 75, at 230.

89. Grand Jury Charge (1759) (unpublished records, 1 Cushing Papers, Massachusetts Historical Society), quoted in W. NeLSON, supra note 58, at 26.

90. ، $\rightarrow$ Howe, Juries as Judges of Criminal Law, 52 HARv. L. Rev. 582, 601 (1939).

91. See G. Wood, The Creation of the American Republic, 1776-1787, at 297 (1969).

92. Queen v. Makemie, 4 Force, Tracts no. 4, 44 (1707), quoted in J. Goebel \& T. NAUGHTON, supra note 62, at 666.

93. King v. Hughson, Horsmander Papers 120 (1741) (manuscript of New York Historical Society Library), quoted in J. GoEBEL \& T. NAUGHTON, supra note 62, at 667.

94. Pledger v. Wade, 1 S.C.L. (1 Bay) 35, 36 (1786).

95. Eveleigh v. Administrators of Stitt, 1 S.C.L. (1 Bay) 92, 92 (1789). See also Liber v. Executors of Parsons, 1 S.C.L. (1 Bay) 19 (1785).

96. Commonwealth v. Garth, 3 Leigh 761, 773, 30 Va. 825, 838 (General Ct. 1831) (Leigh's amicus curiae brief). See also W. Nelson, supra note 58, at 26. 
Instructions were also ineffective because they were often contradictory. One potential source of contradiction was counsel, who on summation could argue the law as well as the facts, at least in Georgia, Massachusetts, New York, Pennsylvania, South Carolina and Virginia, ${ }^{97}$ and probably in other colonies for which no direct evidence is available. Most confusing of all was the court's seriatim charge. Nearly every court in eighteenth-century America sat with more than one judge upon the bench, ${ }^{98}$ and it appears to have been

97. For Georgia, see Robinson v. Adkins, 19 Ga. 398, 400, 402 (1856); Thornton v. Lane, $11 \mathrm{Ga} .459,485$ (1852). These cases probably mirrored prior practice, since the nineteenth century's general trend was to limit counsel's right to argue. For Massachusetts, see W. NELson, supra note 58, at 26, 28-30. For New York, see J. Goebel \& T. NAUGHTON, supra note 62, at 660-66; Letter from Cadwallader Colden to the Earl of Halifax (Dec. 13, 1764), reprinted in 7 Documents Relative to the Colonial History of the State of New York 681, 682 (E. O'Callaghan ed. 1856). For Pennsylvania, see Boehm v. Engle, 1 Dall. 15 (Pa. 1767); testimony of Judge Edward Tilghman, reprinted in REPORT OF THE TRIAL OF THE HONORABLE Samuel Chase 27 (1805). In Georgia v. Brailsford, 3 U.S. (3 Dall.) 1, 3 (1794), a Supreme Court case heard before a Philadelphia jury, opposing counsels' arguments on the law lasted for four days, after which Chief Justice Jay informed the box that the case had "been treated by the Counsel with great learning, diligence and ability; and on your part it has been heard with particular attention . . . . [Y]ou are now, if ever you can be, completely possessed of the merits of the cause." For South Carolina, see Payne v. Trezevant, 2 S.C.L. (2 Bay) 23 (1796); Pringle v. Executors of Witten, 1 S.C.L. (1 Bay) 256, 259 (1792). For Virginia, see Letter from James Maury to John Camm (Dec. 12, 1763), reprinted in J. FonTAINE, Memoirs of A HuGUenot FAMIly 421-23 (1872) (discussing Parson's Cause (1763), see note 110 infra).

98. For Connecticut, see 5 The Public Records of the Colony of Connecticut, 23840 (C. Hoadly ed. 1870) (records of 1711); 8 id. at 91 (1874) (records of 1737); G. CLARK, A History OF CONNECTICUT 85 (1914); Hewitt, The Administration of Justice in Connecticut, in 3 History of CONNECTICUT 137 (N. Osborn ed. 1925). For Georgia, see 7 The Colonial Records of the STATE of Georgia 43-45, 57 (A. Chandler ed. 1904-1916) (records of 1754), id. at 504 (records of 1757); 18 id. at 378-79 (1910) (records of 1760); A. SAYE, A ConstituTIONAL History OF GeORGIA, 1732-1968, at 63 (rev. ed. 1970); Flippin, The Royal Government in Georgia, 1752-1776: VI. The Judicial System and Administration, 10 GA. HIST. Q. 251, 26061 (1926). For Maryland, see 22 ARChIVES of MARYLAND 494 (B. Steiner ed. 1902-1910) (records of 1699); 23 id. at 128-30 (records of 1697); 27 id. at 367 (records of 1708); 30 id. at 299 (records of 1715); N. Mereness, Maryland as a Proprietary Province 237, 246-47 (1901). For Massachusetts, see W. Nelson, supra note 58, at 15-16, 26. For New York, see 1 The Colonial Laws of New York 227-29 (R. Cummings ed. 1894) (records of 1691); id. at 307 (records of 1692); id. at 387 (records of 1699); 2 id. at 466 (records of 1728); 2 id. at 746 (records of 1732); 2 id. at 964 (records of 1737); 3 id. at 188 (records of 1741); 3 id. at 378 (records of 1744); 3 id. at 472 (records of 1745); 3 id. at 1011 (records of 1754); 4 id. at 296 (records of 1758); $4 \mathrm{id}$. at 372 (records of 1759); 4 id. at 969 (records of 1768); 4 id. at 1079 (records of 1769); $4 \mathrm{id}$. at 1088 (records of 1769); 5 id. at 304, 360 (records of 1772); J. GoEBEL \& T. NAUGhton, supra note 62, at 91, 156-68; 2 P. HAMLIN \& C. BAKER, supra note 83, at 5877; Note, Law in Colonial New York: The Legal System of 1691, 80 HARv. L. Rev. 1757, 176467 (1967). For Pennsylvania, see 3 The Statutes at LaRge of Pennsylvania 246 (J. Mitchell \& H. Flanders eds. 1896-1902) (records of 1721); id. at 298 (records of 1722); id. at 302-05 (records of 1722); 4 id. at 88-91 (records of 1727); $7 \mathrm{id}$. at 107-10 (records of 1767); W. Lloyd, The Early Courts of Pennsylvania 74-122 (1910)(reprinted fr $\rightarrow 56$ (old ser.) U. PA. L. Rev. 28 (1908)). After 1767, the Pennsylvania circuit court quorum was reduced to one justice. 7 The Statutes at LaRge of Pennsylvania, supra, at 107-10 (records of 1767). For Virginia, see 3 The Statutes at Large: Being a Collection of the Laws of Vir- 
the general rule for every judge who was sitting to deliver a charge if he wished to do so. Perhaps the most revealing case is Georgia v. Brailsford, ${ }^{99}$ where the Supreme Court of the United States sat in 1793 with a Philadelphia jury in an original action brought by the state of Georgia against the defendant Brailsford. There Chief Justice John Jay, reporting perhaps upon his understanding of the general state of American law, told the jury that it was "fortunate on the present, as it must be on every occasion, to find the opinion of the court unanimous" and to have the court "entertain no diversity of sentiment" and "experience ... no difficulty in uniting in the charge." 100 Such unanimity was not always the case. In both Massachusetts and South Carolina there are examples from the Revolutionary period of judges giving conflicting instructions to juries, ${ }^{101}$ and as late as 1803 Alexander Addison, a Common Pleas judge in Pennsylvania, was successfully impeached for refusing to permit other judges on his court to address juries. ${ }^{102}$ Only in Maryland does the routine practice by counsel of preserving exceptions to objectionable instructions suggest that trial judges were required to deliver a single, correct set of instructions or face the prospect of reversal for error. ${ }^{103}$

GINIA 143 (W. Hening ed. 1810-1823) (records of 1733); 5 id. at 469 (records of 1746); 5 id. at 489-91 (records of 1748); 6 id. at 327 (records of 1769). South Carolina appears to have been exceptional. Apart from the brief period 1721-1731, the colony had no local courts, and at most times the court of common pleas that sat in Charlestown was attended by a single chief justice. See Jenkins v. Putnam, 1 S.C.L. (1 Bay) 8, 8 n. (1784); 3 The Statutes at Large of South Carolina 282-83 (T. Cooper \& D. McCord eds. 1836-1841) (records of 1731); id. at 326 (records of 1731); id. at 555 (records of 1740); id. at 632 (records of 1744); 7 id. at 189-91 (records of 1737); 7 id. at 194 (records of 1767); W. SMITH, SOUTH Carolina AS A RoYal Province, 1719-1776, at 131, 145-47 (1903); E. Whitney, Government of THE Colony of South Carolina 78 (1895). Aside from the regular courts, justices of the peace could try small claims cases without a jury in most colonies.

99. 3 U.S. (3 Dall.) 1 (1794).

100. 3 U.S. (3 Dall.) at 4.

101. See Pateshall v. Apthorp, Quincy 179 (Mass. 1765); Bromfield v. Little, Quincy 108 (Mass. 1764); Hanlon v. Thayer, Quincy 99 (Mass. 1764); Derumple v. Clark, Quincy 38 (Mass. 1763); Jackson v. Foye, Quincy 26 (Mass. 1762); Cooke v. Rhine, 1 S.C.L. (1 Bay) 16 (1784).

102. See Trial of Alexander Addison 16-17, 28-31 (1803). In one Pennsylvania case, the reporter noted that "[t]he Court were unanimous and clear in their opinion . . . ." Boehm v. Engle, 1 Dall. 15, 16 (Pa. 1767). We may infer that such unanimity was worthy of mention.

103. See, e.g., Coursey v. Wright, 1 H. \& McH. 394, 395 (Md. Provincial Ct. 1771); Joce's Lessee v. Harris, 1 H. \& McH. 196, 197 (Md. Provincial Ct. 1754); Crow's Lessee v. Scott, 1 H. \& McH. 182, 184 (Md. Provincial Ct. 1751); Carroll's Lessee v. Llewellin, 1 H. \& McH. 162, 164 (Md. Provincial Ct. 1750); Cheseldine's Lessee v. Brewer, 1 H. \& McH. 152, 152 (Md. Provincial Ct. 1739); Lord Proprietary v. King, 1 H. \& McH. 83, 83 (Md. Provincial Ct. 1732); Digges's Lessee v. Coomes, 1 H. \& McH. 81, 82 (Md. Provincial Ct. 1729); Robinson and Others' Lessee v. Lloyd, 1 H. \& McH. 78, 79 (Md. Provincial Ct. 1728); Robin's Lessee v. Bush, 1 H. \& McH. 50, 51 (Md. Provincial Ct. 1723); Snowden's Lessee v. Lee, 1 H. \& McH. 48, 49 (Md. Provincial Ct. 1722); Sewell's Lessee v. Howard, 1 H. \& McH. 45, 47 (Md. Provincial Ct. 1722). 
Of course, whenever jurors received conflicting instructions, they were left with power to determine which judge's interpretation of the law and the facts was correct. Even when the court's instructions were unanimous, however, juries could not be compelled to adhere to them. Once jurors had received evidence on several factual issues and on the parties' possibly conflicting interpretations of the law, a court could compel them to decide in accordance with its view of the case only by setting aside any verdict contrary either to its statement of the law or to the evidence. By the 1750s English courts, upon motion of the losing party, would set aside such a verdict and order a new trial, ${ }^{104}$ but most eighteenth-century American jurisdictions did not follow English practice.

In Massachusetts, Erving v. Cradock ${ }^{105}$ made clear the court's lack of jurisdiction to set aside a verdict contrary to its instructions. Similarly, the Connecticut Supreme Court in the 1780s denied several new-trial motions on the ground that "[i]t doth not vitiate a verdict, that the jury have mistaken the law or the evidence: for by the practice of this state, they are judges of both."106 The Massachusetts and Connecticut rule appears to have been followed throughout New England. ${ }^{107}$ Maryland and Virginia also followed the same practice. In Maryland, the Provincial Court denied one motion in arrest of judgment which alleged that the "Jury [had] reject[ed] law, reason, and evidence" 108 and another motion for a new trial even though the jury had failed to follow instructions given by the court with the consent of both counsel. ${ }^{109}$ In Virginia, the leading case was the Parson's Cause, ${ }^{110}$ although an earlier case had also declined to

104. See text at notes 85-86 supra.

105. Quincy 553 (Mass. 1761). On the new-trial motion in Massachusetts, see also W. Nelson, supra note 58, at 27-28. In Erving, a shipowner brought an action of trespass against a royal customs collector who had seized his vessel for smuggling and then secured its condemnation in the Court of Vice Admiralty. The collector claimed that the Vice Admiralty decree was res judicata and a complete defense against all liability in the subsequent trespass action, and the superior court so instructed the jury. When the jury nevertheless returned a substantial verdict for the shipowner, both the judges and the other royal officials, including Governor Francis Bernard, agreed that the verdict was binding and could not be set aside.

106. Wittner v. Brewster, Kirby 422, 423 (Conn. Super. Ct. 1788). In addition, see Carpenter v. Child, 1 Root 220 (Conn. Super. Ct. 1790); Pettis v. Warren, Kirby 426 (Conn. Super. Ct. 1788); Taylor v. Geary, Kirby 313 (Conn. Super. Ct. 1787); Wickham v. Waterman, Kirby 273 (Conn. Super. Ct. 1787); Woodruff v. Whittlesey, Kirby 60 (Conn. Super. Ct. 1786).

107. Howe, supra note 90 , at 591.

108. Keech's Lessee v. Dansey, 1 H. \& McH. 20, 21 (Md. Provincial Ct. 1704).

109. Smith's Lessee v. Broughton, 1 H. \& McH. 33 (Md. Provincial Ct. 1714). See note 76 supra. But see Miller's Lessee v. Hynson, 1 H. \& McH. 84 (Md. Provincial Ct. 1734), where the jury attached an erroneous conclusion of law to its special factual findings. Under these circumstances, the court set the verdict aside and ordered a new trial.

110. Reverend James Maury sued in Parson's Cause to collect that portion of salary which the defendant, through Patrick Henry, claimed was barred by an act of the House of Burgesses. 
set aside a verdict which the defendant claimed was contrary to the law. ${ }^{111}$

The same rule also appears to have been followed in four other states, although the evidence is somewhat less clear. In Proprietor $v$. Keith, ${ }^{112}$ a seventeenth-century Pennsylvania prosecution for seditious libel, the court left to the jury all issues of law and fact, including the question whether the publication was actually seditious. In a 1773 civil case in Pennsylvania, the reporter made special note of the fact that "it was agreed by counsel, that the opinion of the court should be conclusive to the jury"113 - a note implying that the opinion would not have been conclusive absent the agreement. In another case the reporter noted that "the jury were of the same opinion" as the court, ${ }^{114}$ thereby suggesting that juries might sometimes have been of a different view. In South Carolina, motions for new trials on the ground that verdicts were against the law were made on four reported occasions in the 1780s and denied without exception, although the courts noted the special circumstances of each case and never articulated a general rule concerning the jury's power to determine the law. ${ }^{115}$ In Georgia, the Constitution of 1777 barred judges from interfering with the jury's power to determine the law, ${ }^{116}$ while New Jersey did the same by statute in $1784 .{ }^{117}$ Both

The court instructed the jury that the Burgesses' act, which had been subsequently disallowed by the Privy Council, was void ab initio and hence that the plaintiff deserved his full salary, but when the jury awarded damages of one penny, the court denied Maury's motion for a new trial on the ground that the verdict contradicted the evidence. Letter from James Maury to John Camm (Dec. 12, 1763), reprinted in J. FONTAINE, supra note 97, at 418-24.

111. Waddill v. Chamberlayne, Jeff. 10 (Va. 1735). It is unclear, however, whether the court agreed with the jury or believed that it lacked the power to dismiss a jury verdict.

112. Reported in S. Penny Packer, Pennsylvania Colonial Cases 117 (1892). See also Testimony of Judge Edward Tilghman, supra note 97, at 27.

113. Anonymous, 1 Dall. 20, 20 (Pa. 1773).

114. Lessee of Albertson v. Robeson, 1 Dall. 9 (Pa. 1764). In Boehm v. Eagle, 1 Dall. 15, 16 (Pa. 1767), the reporter said that the "jury was conformable to [the court's] opinion." And in Lessee of the Proprietary v. Ralston, 1 Dall. 18, 19 (Pa. 1773), the reporter plainly implied that the jury was determining the law when "[a] verdict passed for the plaintiff, by which the sense of the jury was, that the non-performance of conditions of settlement, did not void the grant." Cf. Hurst v. Dippo, 1 Dall. 20, 21 (Pa. 1774) (Chief Justice Chew stated initially that "[i]t is a settled rule, that courts of law determine law; a jury facts," yet proceeded implicitly to ignore his statement, see note 84 supra).

115. Steel, qui tam v. Roach, 1 S.C.L. (1 Bay) 62 (1788); Bourke v. Bulow, 1 S.C.L. (1 Bay) 49 (1787); Pledger v. Wade, 1 S.C.L. (1 Bay) 35 (1786); Mounier v. Meyrey, 1 S.C.L. (1 Bay) 24 (1785). See also White v. McNeily, 1 S.C.L. (1 Bay) 11, 12 (1784), where the jury's apportioning of damages among joint tortfeasors "was at first doubted as a deviation from the old common law rule . . . [that the] jury could not sever." The court, "upon mature consideration," sanctioned the verdict, but it is unclear whether the court recognized the jury's power to decide law or simply considered the jury's verdict a better rule.

116. GA. Const. of $1777, \S 41$.

117. An Act for regulating and shortening the Proceedings in the Courts of Law, ch. 32, 
these provisions probably confirmed pre-existing colonial practice.

Only in New York does evidence exist that judges and other informed commentators believed that a court could grant a new trial if the jury in a civil matter ignored the law, and nearly all this evidence arises from a single 1763 case, Forsey v. Cunningham. ${ }^{118}$ The supreme court denied a new trial motion in Forsey, but several of the justices and Lieutenant Governor Cadwallader Colden all subsequently contended in letters that courts could set aside verdicts that were against law or evidence. ${ }^{119}$ The apparent inconsistency between the justices' statements and their action in Forsey can be resolved in several ways, ${ }^{120}$ but whatever the inconsistency, it does not appear that colonial New York courts routinely granted new trials in civil cases. Indeed, acting as counsel in his own cause, Robert Livingston in 1784 denounced the new trial motion as a "new-fangled doctrine of Lord Mansfield" and added that "no single authority was to be found in its support, in a case of a trial at bar, by a struck jury, in term time." 121 Other lawyers writing about New York practice in that and the next decade still spoke with confusion about the relative powers of court and jury, ${ }^{122}$ and, as late as 1800 , judges did not fully agree that they could set aside a verdict against law or evidence. ${ }^{123}$ In criminal cases, of course, King $v$. Zenger established the power of

$\S 14$ (1784), 1784 N.J. Acts 80 . New Jersey's act prohibited trial courts from vacating jury verdicts, but did make verdicts subject to reversal by the Court of Error.

118. (N.Y. Sup. Ct., 1763), discussed in J. Smith, Appeals to the Privy Council from the American Plantations 390-416 (1950).

119. See the statements of Judges Jones and Livingston in Report of the Case Between Forsey and Cunningham, New-York Gazette; or, The Weekly Post-Boy, Jan. 31, 1765, at 1, col. 3 and at 2, col. 1; Letter from Cadwallader Colden to the Earl of Halifax (Dec. 13, 1764), supra note 97 , at $682-84$.

120. Possible explanations for the New York Supreme Court's action in Forsey are (1) that the court did not consider the verdict to be against law or evidence, and hence would not set it aside on that ground; (2) that the court did consider the verdict to be against evidence, but held the granting of a new trial under such conditions to be an act of discretion which it chose not to exercise in the instant case. On the discretionary aspect of the new trial doctrine, see Wood $v$. Gunston, Style 466, 82 Eng. Rep. 867 (K.B. 1655); Letter from Cadwallader Colden to the Earl of Halifax (Dec. 13, 1764), supra note 97, at 682. Or, the court may (3) have distinguished sharply between verdicts against evidence and excessive damages. In Forsey, the finding against the defendant was justified and acknowledged; only the amount of compensation which the jury ordered was contested. On this distinction, see M. Horwitz, The TransforMATION OF AMERICAN LAW, 1780-1860, at 28-29 (1977).

121. J. Kent, An Address Delivered Before the Law Association of the City of New York (Oct. 21, 1836), reprinted in (pts. 1-2) 2 Colum. JUR. 110, 122, at 123 (1885).

122. Compare 1 The Law Practice of Alexander Hamilton 118 (J. Goebel ed. 1964) and W. Wyche, supra note 79, at 168, with 1 The Law Practice of Alexander Hamilton, supra at 120, and W. WYCHE, supra note 79, at 176.

123. In the two cases of Wilkie v. Roosevelt, 3 Johns. Cas. 66 (N.Y. Sup. Ct. 1802); 3 Johns. Cas. 206 (N.Y. Sup. Ct. 1802), Judges Thompson, Radcliff and Kent ruled in favor of a new trial; Chief Judge Lewis and Judge Livingston dissented. The Wilkie juries clearly expressed their feelings on the issue of vacating verdicts by thrice defying the court's instructions; 
juries to determine law as well as fact, ${ }^{124}$ although convictions were set aside in a few cases because juries misapplied the law. ${ }^{125}$

Thus, the various eighteenth-century procedural devices for controlling the power of the jury were only infrequently used and partially effective. It accordingly seems safe to conclude that juries in most, if not all, eighteenth-century American jurisdictions normally had the power to determine law as well as fact in both civil and criminal cases. Statements of contemporary lawyers, moreover, buttress this conclusion; Zephaniah Swift of Connecticut and Robert Treat Paine of Massachusetts said that " $[t]$ he jury were the proper judges, not only of the fact but of the law that was necessarily involved"126 in each case; that the "Jury ha[d] a right to do as they please[d];"127 and that "no verdicts . . . [were] thrown out."128

Even more telling, perhaps, are statements by three of the most eminent lawyers in late eighteenth-century America-John Adams, Thomas Jefferson, and John Jay. In the early 1770s, Adams observed in his diary: "It was never yet disputed, or doubted, that a general Verdict, given under the Direction of the Court in Point of Law, was a legal Determination of the Issue." 129 Adams argued that even a verdict contrary to the court's directions should stand, for it was "not only . . . [every juror's] right but his Duty in that Case to find the Verdict according to his own best Understanding, Judgment and Conscience, tho in Direct opposition to the Direction of the Court." 130 In 1781-1782, Thomas Jefferson painted an equally broad picture of the power of juries over the law in his Notes on Virginia. "It is usual for the jurors to decide the fact, and to refer the law arising on it to the decision of the judges," Jefferson wrote. "But this division of the subject lies with their discretion only. And if the question relate to any point of public liberty, or if it be one of those in which the judges may be suspected of bias, the jury undertake to

after the third trial the litigants accepted the jury's perverse verdict. The case is discussed in 2 The Law Practice of Alexander Hamilton, supra note 122, at 228-31.

124. See J. Goebel \& T. Naughton, supra note 62, at 239-40, 278-79, 588-89, 666, 669; see, e.g., People v. Barrett, 1 Johns. 66 (N.Y. Sup. Ct. 1806).

125. See J. Goebel \& T. Naughton, supra note 62, at 278-79; see, e.g., People v. Townsend, 1 Johns. Cas. 104 (N.Y. Sup. Ct. 1799).

126. 1 Z. Swift, A System of the Law of the State of Connecticut 410 (1795); 2 id. 257-59 (1796).

127. Lyon v. Cobb (Bristol County Ct. of C.P. 1769), quoted in W. Nelson, supra note 58, at 28 (argument of counsel).

128. Quincy v. Howard (Bristol County Ct. of C.P. 1770), quoted in W. NELSON, supra note 58, at 28 (argument of counsel).

129. I Legal Papers of John Adams, supra note 75, at 230 (emphasis original).

130. Id. 
decide both law and fact."131 As late as 1793, John Jay, sitting as Chief Justice of the United States, informed a civil jury that while the court usually determined the law and the jury found the facts, the jury nevertheless had "a right to take upon yourselves to judge of both, and to determine the law as well as the fact in controversy." "[B]oth objects," Jay concluded, "are lawfully, within your power of decision." 132

The power of juries to determine law as well as fact reveals a great deal about many aspects of government and society in eighteenth-century America. However, I shall not explore all the inferences about the eighteenth century that historians might draw from the law-finding power of juries. I am concerned with the efforts of John Marshall and other early nineteenth-century judges to apply eighteenth-century governmental techniques to the resolution of nineteenth-century problems. Accordingly, I shall consider only how the eighteenth-century jury's law-finding power can help us see early nineteenth-century cases from a new perspective.

\section{Shared Values as the Basis of Eighteenth-Century Law}

That eighteenth-century juries often decided cases after receiving rudimentary, conflicting, or no instructions from the court suggests that many jurors came to court with preconceptions about the substance of the law. This point was explicitly made in the 1788 Connecticut case of Pettis v. Warren. ${ }^{133}$ In a black slave's suit for freedom, one juror was challenged for having a pre-existing opinion " "that no negro, by the laws of this state, could be holden a slave.", Affirming the trial court's overruling of the challenge, the Connecticut Supreme Court held that "[a]n opinion formed and declared upon a general principle of law, does not disqualify a juror to sit in a cause in which that principle applies." Indeed, the court observed that the jurors in every case could "all be challenged on one side or the other, if having an opinion of the law in the case is ground of challenge," 134 since, as John Adams had once noted, "[t]he general Rules of Law and common Regulations of Society . . . [were] well enough known to ordinary Jurors."135 Jurors, the Connecticut court

131. T. Jefferson, Notes on the State of Virginia 140 (J. Randolph ed. 1853).

132. Georgia v. Brailsford, 3 U.S. (3 Dall.) 1, 4 (1794).

133. Kirby 426 (Conn. Sup. Ct. 1788).

134. Kirby at 427.

135. 1 Legal Papers of John Adams, supra note 75, at 230. 
believed, were "supposed to have opinions of what the law is," since they sat as "judges of law as well as fact."136

One might infer further that jurors came to the court with similar preconceptions about the law, at least as it applied to disputes that frequently came before them. Indeed, one cannot escape this inference without abandoning all efforts to understand how eighteenthcentury government functioned. If jurors came to court with different and possibly conflicting opinions about substantive law, one would expect to find first, that juries had difficulty reaching unanimous verdicts and that mistrials due to hung juries were correspondingly frequent, and second, that different juries at different times would reach different, perhaps inconsistent verdicts, thereby making the law so uncertain and unpredictable that people could not plan their affairs. In fact, no such evidence exists. On the contrary, the available evidence suggests that juries had so little difficulty reaching verdicts that they often heard and decided several cases a day. ${ }^{137}$ No one in the mid-eighteenth century complained about the inconsistency of the jury verdicts, and as soon as such complaints were heard in the century's last decade, ${ }^{138}$ the system of jury law-finding began to disintegrate. ${ }^{139}$

Although we have no direct evidence, most men probably did not desire to serve as jurors. ${ }^{140}$ At a time of difficult travel, few men

136. Kirby at 427.

137. Wroth \& Zobel, Introduction, supra note 73, at xlvii. Most extant eighteenth-century court records show that courts rarely met for terms exceeding several days and that they often disposed of more than 100 cases during those terms, many of them by jury verdicts.

138. See R. Ellis, supra note 17, at 190; M. HoRwITZ, supra note 120, at 28; W. Nelson, supra note 58 , at $165 ; 2$ Z. SwIFT, supra note 126, at 257-59.

139. Between 1790 and 1820 , courts in nearly every state for which evidence exists began to grant motions for new trials in civil cases where juries returned verdicts contrary to law, instructions, or evidence. See The Public Statute Laws of the State of Connecticut, tit. 2, § 54 (1821); Robinson v. Adkins, 19 Ga. 398, 400-02 (1856); Bank v. Marchand, 1 Charlt. 247 (Ga. Super. Ct. 1809); The General Public Statutory Law and Public Local Law of the State of Maryland, ch. 42 (1790) (C. Dorsey ed. 1840); W. Nelson, supra note 58, at 168-69; Mumford v. Smith, 1 Cai. R. 520 (N.Y. Sup. Ct. 1804); Jackson v. Bowen, 1 Cai. R. 358 (N.Y. Sup. Ct. 1803); Dow v. Smith, I Cai. R. 32 (N.Y. 1803); Swearingen v. Birch, 4 Yeates 322 (Pa. 1806); Cowperthwaite v. Jones, 2 Dall. 55 (Pa. 1796); Steinmetz v. Currey, 1 Dall. 234 (Pa. 1788); Payne v. Trezevant, 2 S.C.L. (2 Bay) 23, 32 (1790); Administrators of Moore v. Cherry, 1 S.C.L. (1 Bay) 267 (1792); Hawkins's Exrs. v. Berkley, 1 Va. (1 Wash.) 204 (1793). The routine granting of such motions deprived juries of final authority to determine law, but it did not transfer ultimate authority to the courts, which were not authorized to grant judgments notwithstanding the verdict in civil cases until after 1820. See Parks v. Ross, 52 U.S. (11 How.) 362 (1850); Dox v. Postmaster-General, 26 U.S. (1 Pet.) 318, 320 (1828); Denny v. Williams, 87 Mass. (5 Allen) 1 (1862); Burdick v. Green, 18 Johns. 14, 20 (N.Y. Sup. Ct. 1820). See gener $\rightarrow$ Hackett, Has a Trial Judge of a United States Court the Right To Direct a Verdict?, 24 YALE L. J. 127 (1914). In criminal cases, jury power over law remained extensive well into the nineteenth century. See generally Howe, supra note 90.

140. Under eighteenth-century law, jurors were selected by one of several largely random processes: they were chosen by lot from a list of freeholders, elected by the voters of the jurisdiction, or summoned by the sheriff from among the bystanders at court. See, e.g., 9 THE 
would have cared to attend court sessions, and those who did probably were pursuing business interests from which jury duty was an unwelcome distraction. In short, there is every reason to think that eighteenth-century citizens avoided jury duty as eagerly as citizens today and that the chore was therefore distributed among as much of the eligible population as could be conscripted. ${ }^{141}$ Although some groups (notably women, blacks, servants, religious dissenters, and anyone who did not own land or pay taxes) may have been systematically excluded from juries, ${ }^{142}$ it does not seem unreasonable to infer that juries contained a random and representative cross section of the remaining population. ${ }^{143}$

That conclusion suggests a final inference. If juries in fact mirrored the white, male, landowning, and taxpaying population, and if upon coming to court nearly all jurors shared similar ideas about the substance of the law, then perhaps a body of shared ideas about law permeated a large segment of the population of every territory over which a court that sat with a jury had jurisdiction. Colonial government may have been able to derive policies from and otherwise function on the basis of those shared values.

Those who live amidst the twentieth-century cacophony of conflicting interests may find it difficult to imagine how a government acting only in the absence of serious conflict could ever function effectively. The eighteenth-century Anglo-American world, however, was sufficiently different from our own so that government in that era might have so functioned.

Public Records of the Colony of Connecticut, supra note 98, at 45-46 (records of 1744); 18 The Colonial Records of the State of Georgia, supra note 98, at 144-57 (records of 1756); 3 The Colonial LAwS OF NEW YORK, supra note 98, at 185-92 (records of 1741); 3 The Statutes at Large of South Carolina, supra note 98, at 274-81 (records of 1731); 3 The Statutes at LaRge: Being a Collection of the Laws of Virginia, supra note 98, at 369-70 (records of 1704); 5 id. at 24-26 (records of 1738); 5 id. at 523-36 (records of 1748); 5 id. at 544-45 (records of 1748); 3 The Legal Papers of John Adams, supra note 75, at 17-18.

141. The one available local study indicates, in fact, that between one-fourth and one-third of all adult males served on juries. See Nelson, Introductory Essay, The Larger Context of Litigation in Plymouth County 1725-1825, in 1 LEGAL ReCORDS OF Plymouth County 16861859, at 25 (D. Konig ed. 1978).

142. On the property and tax requirements for service on juries, see 5 THE PUbLIC RECORDS OF THE COLONY OF CONNECTICUT, supra note 98, at 240 (records of 1711); 9 id. at 45 (records of 1744); 9 id. at 247 (records of 1746); 1 THE Colonial LAws OF New YoRK, supra note 98, at 387 (records of 1699); 3 id. at 185 (records of 1741); 3 THE STATUTES AT LARGe of South Carolina, supra note 98, at 274-82 (records of 1731); 5 The Statutes at LARGE: BEING A COLlection OF THE LAwS OF VIRGINIA, supra note 98, at 24-25 (records of 1738); id. at 489-91 (records of 1748); id. at 525 (records of 1748); id. at 544-45 (records of 1748). See also A. Porter, County Government in Virginia 49 (1947). On exclusion of dissenters from juries, see W. Nelson, supra note 58, at 113; Nelson, supra note 141, at 25.

143. Cf. C. Williamson, American Suffrage 20-39 (1960), which concludes that between one-half and three-fourths of all adult white males were qualified to vote in most localities in eighteenth-century America. 
Several differences should be noted. First, the primitive character of the economy meant that most communities could afford only a few salaried officeholders. ${ }^{144}$ Indeed, many men did not have enough wealth and time even to participate in elections "without manifest injury to their crops." 145 As a result, competition for local leadership positions was often understandably slight, ${ }^{146}$ and local governments lacked substantial salaried bureaucracies that could enforce decisions. Part-time police officials such as deputy sheriffs and constables enforced government decisions, so long, that is, as they did not contravene the wishes of neighbors with whom they had close economic and social ties. ${ }^{147}$ The ultimate enforcement body - the militia - was merely the community itself organized as a quasi-military body that would, of course, not act against the community's wishes. Colonial economic conditions, in short, reduced conflict and competition in local politics and precluded the rise of coercive institutions that might have been used by one portion of a community seeking to promote its interests at the expense of others.

Second, colonial American communities differed tremendously. Religion remained important in eighteenth-century life, and America could afford room for almost any religious community. ${ }^{148}$ Religious differences were not the only ones among the communities. Important economic differences also existed, for while most communities were agricultural, some were either mercantile or chiefly engaged in fishing. Finally, inarticulable differences in lifestyle and ambience distinguished communities, as any visitor of the restored colonial towns of Sturbridge, Massachusetts, and Williams-

144. Virginia justices, for example, received neither salary nor fee for their services. See C. Sydnor, Gentlemen Freeholders, supra note 58, at 84 . The fees paid to Massachusetts judges and judicial officers were not particularly high either. See Wroth \& Zobel, Introduction, supra note 73, at lxix-lxxi.

145. Freeholders' Appeal to the Governor, quoted in C. Sydnor, Gentlemen FreeHoldERS, supra note 58 , at 33 .

146. That local officials had to be compelled by law to serve evinces the lack of competition for many local offices. See W. Nelson, supra note 58 , at 38 . $\rightarrow$ Greenberg, The Effectiveness of Law Enforcement in Eighteenth-Century New York, 19 AM. J. LEGAL HIST. 173, 174-86 (1975)(finding qualified men willing to serve as law enforcement officers was difficult). At times, even legislative elections were not competitive. See P. BonOMI, supra note 58, at 190.

147. See Greenberg, supra note 146, at 175. $\rightarrow$ Nelson, The Legal Restraint of Power in Pre-Revolutionary America: Massachusetts as a Case Study, 1760-1775, 18 AM. J. LEGAL HiST. 1, 7-9, 30-32 (1974).

148. Puritan communities prevailed, of course, in New England, as Anglican communities did throughout the South, but Dutch Calvinists established communities in New York, Quakers settled in Pennsylvania, and Baptists and Presbyterians scattered communities along the frontier. Other sorts of Protestant communities also existed, as well as Roman Catholic communities in Maryland and even a Jewish community in New York. See H. Grinstein, The Rise of THE Jewish COMMUNity OF New YoRK, 1654-1860 (1945); H. Browne, Catholicism in the United States, in The Shaping of AmERican Religion 72, $74-75$ (1961). 
burg, Virginia, can see, or as any reader of the diaries of eighteenthcentury travellers like Dr. Alexander Hamilton can learn. ${ }^{149}$

Colonials did not find it especially difficult to change their residence from one community to another. Benjamin Franklin, for example, moved from Boston to Philadelphia with relative ease, 150 while thousands of colonial Americans found the move from established towns to the frontier not at all insuperable. ${ }^{151}$ As a result, most colonials who dissented from their own community's conception of right and justice could move without great difficulty to a more congenial community. Newly arriving immigrants were also able to identify and settle in communities that welcomed their religious beliefs, lifestyles, and economic skills. ${ }^{152}$ The tendency of people to live in communities they found congenial was important, particularly because it enabled communities to retain their identity by facilitating the departure of those whose personal ethical codes would have diluted that identity.

But while colonial Americans could readily move between communities, they generally seem not to have established the kind of sustained intercommunity contact likely to produce conflict. American communities had long since abandoned schemes of subjugating each other or seizing each other's wealth; the Dutch of Manhattan and the Puritans of Long Island, for example, learned how to coexist when they each abandoned thoughts of conquest and developed their primary social and economic communication with their respective compatriots in the Hudson Valley and in New England rather than with each other. ${ }^{153}$ The availability of land, ${ }^{154}$ which made territorial quarrels unnecessary, and the lack of a developed transporta-

149. See Alexander Hamilton, Gentlemen's Progress (C. Bridenbaugh ed. 1948).

150. See C. Van Doren, Benjamin Franklin 37-44 (1938).

151. C. Grant, Democracy in the Connecticut Frontier Town of Kent 28-103 (1961), discusses one example of the ease of settlement. In particular, Grant shows that in the 22 years following Kent's founding in 1738, 772 different men bought land in the town, $61 \%$ of whom took up residence. Id. at 56 .

152. News of the different colonies' willingness to receive immigrants filtered back to Europe in vast quantities. See M. Hansen, The Atlantic Migration, 1607-1860, at 32-52 (1940); Conway, Welsh Emigration to the United States, in 7 PERSPECTIVES IN AMERICAN HISTORY 175, 185-88 (1973); Köllmann \& Marschalck, German Emigration to the United States, in 7 Perspectives In American History 497, 512-15 (1973); Schelbert, On Becoming an Emigrant: A Structural View of Eighteenth-and Nineteenth-Century Swiss Data, in 7 PERSPECTIVES IN AMERICAN HISTORY 439, 464-67, 477-80 (1973).

153. See D. Fox, YANKeES AND YORKERS 57-151 (1940).

154. See M. HANSEN, supra note 152, at 45 . Until the middle of the eighteenth century, even the smaller and older colonies like Connecticut had free land on which new towns could be founded. See C. Grant, supra note 151, at 3-11. 
tion and communication network, ${ }^{155}$ which made sustained contact difficult, also help account for the infrequency of disputes between communities. Geographically proximate communities were thus able to remain distinct, ${ }^{156}$ to pursue their own conception of right, and to avoid intercommunity disputes which legal institutions dependent on local community support would have been incapable of resolving. ${ }^{157}$

Finally, colonial politics existed within an established constitutional structure which colonials could not control. Parliament, in which colonials had no direct voice, alone possessed the power to decide many fundamental social and economic issues, and for the first sixty years of the eighteenth century it was willing to abide by decisions reached in the preceding century which were often favorable to the colonies. Thus, much of the grist for genuine political conflict was removed from the realm of imperial politics; absent a radical restructuring of the Anglo-American system, there was simply no point in building a political organization around the issue whether, for example, Anglicans would be tolerated in Massachusetts ${ }^{158}$ or whether Americans would be free to trade with French Canada without restriction. ${ }^{159}$

Provincial politics were not radically different. Americans controlled their colonial legislatures, but they could not effectively enact legislation that significantly altered the structure of colonial society since such legislation would almost always be vetoed by a colonial governor or by London. ${ }^{160}$ As a result, colonial legislation usually consisted of mere administration: raising and appropriating small amounts of tax money, distributing the even smaller amounts of government largess, and legislating as necessary to keep the few governmental institutions functioning. ${ }^{161}$ While provincial political conflict commonly occurred, it rarely involved important social issues. ${ }^{162}$ Of

155. See C. Nettels, The Emergence of a National Economy, 1775-1815, at 38-40 (1962).

156. See P. BonOMI, supra note 58 , at 24-28.

157. For one example of the inability of outsiders to obtain justice from local legal institutions, see $i d$. at 51 .

158. Pressure from London forced Massachusetts to treat Anglicans as a separate denomination exempt from religious taxation. See C. Bridenbaugh, Mitre ANd SCEPTRE 73-74 (1962).

159. The Navigation Acts, of course, prohibited trade between the colonies and French Canada. See note 62 supra.

160. For example, English authorities overrode Massachusetts' land-bank legislation. See J. Schutz, William Shirley, King's Governor of Massachusetts 40 (1961).

161. See W. Nelson, supra note 58 , at 14.

162. See generally B. Bailyn, The Origins of American Politics (1968); S. Katz, NeWCASTLE'S NEW YoRK 44-58 (1968); J. SCHUTZ, supra note 160. 
course, occasional conflicts grew from religious differences, such as the division in Pennsylvania politics between Quaker and antiQuaker parties, ${ }^{163}$ and from the rivalry between seaboard and backcountry areas, such as the 1740s land-bank dispute in Massachusetts $^{164}$ and the 1760 s Regulator Movement in the Carolinas. ${ }^{165}$ But since these disputes could not be locally resolved within the British power structure, they quickly degenerated into mere personal and factional conflicts between men seeking personal advancement. ${ }^{166}$ Provincial political conflict may have been widespread, but as shrewdly observant colonial political writers vehemently announced, it departed from the ideal polity of consensus ${ }^{167}$-a polity that may have existed in many eighteenth-century local communities.

Taken together, these facts may have helped to sustain a political order in colonial America radically different from the political order of America today. The stable imperial constitution combined with primitive colonial economies to remove most social and economic issues from imperial and provincial politics. Before Independence, most newly arising socioeconomic conflicts were resolved and new socioeconomic decisions taken at the local level. The primitiveness of the colonial economy had another influence: by keeping the social elite small and depriving it of effective military and bureaucratic power necessary to coerce the people at large, the colonial American economic system denied colonial leaders the opportunity to exploit their localities in their own self-interest. Colonial leaders generally had to govern and resolve social tensions according to values commonly accepted in their localities. Finally, the real differences between localities and the ease with which people could move to a community whose ideas they shared preserved each community's distinct identity. As a result, the colonial American polity may on the whole have consisted of a series of local communities whose inhabitants jointly defined standards of right and justice and insured that the community lived by those standards.

But it is unnecessary for purposes of this essay to insist upon this portrait of eighteenth-century America, especially since other evidence suggests that any such communitarian social order had at least

163. See J. Hutson, Pennsylvania Politics, 1746-1770, at 130 (1972).

164. See J. SchuTZ, supra note 160, at 37-40.

165. See R. Brown, The South Carolina Regulators 38-63 (1963).

166. See J. Hutson, supra note 163, at 130-77; J. SchuTZ, supra note 160, at 48-57, 62-63.

167. See B. BAILYN, supra note 162 , at $64-65$. 
partially broken down. ${ }^{168}$ Nor need this essay insist that colonial government functioned according to shared values with more than a minimal effectiveness. The only important point is that a consensus style of government was intimately known to mid-eighteenth-century Americans on a routine, day-to-day basis. An individual litigant, a special interest group, a high provincial official, even a judge, often could elicit a particular court decision or attain a long-term policy only if he could persuade the cross section of his community that acted as jurors, and his attempts at persuasion must almost invariably have required appeals to values he and the jurors shared. Since eighteenth-century juries rarely could be circumvented or coerced, there was normally no other way to proceed.

Of course, lawyers, judges, officials, and litigants did not always find common values which could support decisions. They may often have failed, and their failures may have sensitized them to the instability inherent in processes of government by consensus. Nevertheless, the mid-eighteenth-century statesman typically governed, the lawyer practiced, and the litigant argued, by molding and appealing to a consensus of shared values. It was in this style of government and legal practice that John Marshall and other statesmen, judges, and lawyers of his generation first learned their professions.

\section{The Birth of National Party Conflict}

At the outset of the War of Independence, most rebelling colonists aimed not so much to change as to preserve the basic structure of their political system. In particular, most Americans wished to preserve a political order which generally required officials to govern according to common values or principles which nearly all citizens accepted as right or otherwise legitimate. ${ }^{169}$ Nevertheless, independence significantly reshaped American politics by introducing a new political style in stark contrast to the mid-eighteenth-century style of government by consensus.

Independence destroyed the stability of the imperial system. No longer were fundamental questions such as the distribution of power among various levels of government, the continuance of religious establishments, and the freedom of American merchants to trade abroad resolved by an imperial law which the colonies had little di-

168. See Nelson, supra note 141; Gordon, Book Review, 51 N.Y.U.L. REv. 686, 687-90 (1976); Murrin, Review Essay, 11 Hist. \& THEORY 226, 245-57 (19 $\rightarrow$ Wroth, Review Essay, 15 Am. J. Legal Hist. 318 (1971).

169. See B. Bailyn, The Ideological Origins of the American Revolution 94-95, 102-09, 118-21, 160-62, 188-90, 202-05 (1967); W. Nelson, supra note 58, at 67. 
rect power to control. Independence compelled Americans to resolve such questions anew, and to do so nationally rather than locally. The post-Revolutionary generation's grapplings with these questions portended social discord in both state and national politics and during the last two decades of the eighteenth century provoked some of the most vituperative conflict in American political history.

The revolutionary struggle and the attainment of independence also transformed American society and politics ideologically. In discarding British rule and reconstituting their governments, Americans proclaimed that all law springs from popular will, at least insofar as elected representatives express popular will in legislation. If the people could remake their government, it followed that their lawmaking power must be "original, inherent, and unlimited by human authority." 170 In short, the Revolution convinced many Americans that popular will was "the only rational source of power"171 and that there was "an original, underived and incommunicable authority and supremacy in the collective body of the people to whom all delegated power must submit and from whom there is no appeal." 172

This concept of legislation as the creation of new law by the people or their representatives proved practically significant after independence because groups such as religious dissenters and westward expansionists used it to promote their interests. Before the Revolution, policies imposed by London had tended to restrict westward expansion ${ }^{173}$ and to require that dissenters support the established churches. ${ }^{174}$ Once independent Americans could formulate their own policies, however, both religious dissenters and westward expansionists campaigned to revise established policies. Legislatures frequently responded by changing inherited rules and practices, ${ }^{175}$ and in the process changed themselves as well. By enacting new law, legislatures reinforced the ideology of popular lawmaking power and forged an active, creative legislative process in lieu of one which depended on the derivation of rules from preexisting principles.

This transformation occurred, however, in a society unprepared

170. [Baltimore] Maryland Journal, Feb. 20, 1787, quoted in G. Wood, supra note 91, at 371. See also id. at 368.

171. Zabdiel Adams, Sermon Preached Before . . the Senate and House of Representatives of the Commonwealth of Massachusetts, May 29, 1782, at 20 (Boston 1782).

172. [Hartford] Connecticut Courant \& Weekly Intelligence, Aug. 12, 1783, at 2, col. 3.

173. P. Gates, history of Public Land Law Development 34 (1968).

174. See P. Miller, The Life of The Mind in America 36-43, 66-72 (1965).

175. Soon after the Revolution, Virginia, North Carolina, Pennsylvania, and Massachusetts passed legislation to protect squatters' rights in western lands. P. GATES, supra note 173, at 66-67. 
to abandon blithely the pre-Revolutionary ideal that human law must conform to fundamental principles of divine or natural law. The older ideal persisted throughout the late 1770s and the 1780s. After all, as Edmund Randolph observed in retrospect, "theoretic reasoning" had brought about the Revolution itself. ${ }^{176}$ Post-Revolutionary Americans continued to maintain that they could rationally "define the rights of nature" and learn "how to search into, to distinguish, and to comprehend, the principles of physical, moral, religious, and civil liberty." 177 Believing in "eternal principles of social justice," 178 American political thinkers of the 1780s continued to object to legislation "founded not upon the principles of Justice, but upon the Right of the Sword" and to legislation for which "no other Reason can be given .. . than because the Legislature had the Power and Will to enact such a Law."179 They believed that legislatures which enacted laws that "violate[d] . . . fundamental principles ... [were] substituting power for right."180 Thinkers like Madison, arguing at the time of the Constitutional Convention for a congressional power to negate state legislation, noted that America needed "some disinterested \& dispassionate umpire" to control "disputes between different passions $\&$ interests in the State[s]."181

In short, many Americans believed after the Revolution that government should articulate and apply fundamental principles dispassionately, neutrally, and objectively, rather than yield to a mere electoral majority. Some, like Madison, thought that legislatures, not courts, should guard fundamental legal principles, while others, like Hamilton, argued that courts as well as legislatures should do so. ${ }^{182}$ But, since courts throughout the 1780 s were still generally considered an undifferentiated segment of the executive branch, the important issue for that decade was not whether the legislative, executive or the judicial branch should ensure the conformity of law

176. E. RANDOlPH, MANUSCRIPT History OF VIRGINIA, quoted in G. Wood., supra note 91, at 4.

177. W. Pierce, An Oration, Delivered at Christ Church, Savannah, on the 4th July, 1788, in COMMEMORATION OF THE ANNIVERSARY OF AMERICAN INDEPENDENCE 6 (Savannah 1788).

178. 3 Papers of Alexander Hamilton 550 (H. Syrett \& J. Cooke eds. 1962) (Hamilton's Second Letter from Phocion [1784]).

179. Petition of Salem, Oct. 12, 1784, quoted in McCormick, New Jersey IN THE CritiCAL Period 183, cited in G. Wood, supra note 91, at 406 n.22.

180. Providence [R.I.] Gazette \& Country Journal, Aug. 5, 1786, at 2, col. 2.

181. 2 The Writings of James Madison 346 (G. Hunt ed. 1901) (letter to G. Washington, April 16, 1787).

182. See The Federalist No. 78 (A. Hamilton). 
to fundamental standards of right, but whether any institution should.

At times during that decade, legislatures were asked to protect those fundamental standards. Arguments were made against legislation such as a Virginia act which condemned to death an alleged highway robber "without any proof better than vague reports . . . [,] without being confronted with his accusers and witnesses, [and] without the privilege of calling for evidence in his behalf . . . ."183 To those who believed that law must adhere to immutable principles that transcend popular will, "this arbitrary deprivation of life, the dearest gift of God to man," was neither "consistent with the genius of republican government" nor "compatible with the spirit of freedom"; they could "not contemplate it without horror."184 Others responded that the collective body of the people possessed "plenary power" to make law; if the people were to exercise an "unlimited power to do right," then they must also have "an unlimited power to do wrong." 185 Granting any group of men the power to nullify acts of the people, the argument added, "would be more despotic than the Roman Decemvirate," for who could then "check or control" those men. ${ }^{186}$

At other times during the 1780s the courts heard demands for the protection of fundamental rights in cases akin to modern requests for judicial review. In four reported cases from North Carolina, Rhode Island, and Virginia, ${ }^{187}$ courts asserted the power to invalidate unconstitutional legislation; in two other cases from New York and South Carolina, ${ }^{188}$ they effectively struck down statutes under the guise of interpretation. Massachusetts and New Hampshire courts

183. 3 The Debates in the Several State Conventions on the adoption of the Federal Constitution 66-67 (2d ed. J. Elliot 1836) [hereinafter cited as Debates]. The Virginia act is discussed in $2 \mathrm{~W}$. CROSSKEY, supra note 9, at 945-47, who contends that the robber was executed not pursuant to the legislative act, but pursuant to a jury verdict returned on a criminal indictment.

184. 3 DeBATES, supra note 183 , at 67

185. Webster, Government, 1 AM. MAG. 75-76 (1787-1788).

186. Letter from Richard D. Spaight to James Iredell (Aug. 12, 1757), reprinted in 2 G. MCReE, Life AND CoRResPondence of JAMES IREDELl 168, 169 (New York 1857). The quoted statement was made by Richard Spraight, while a delegate at the Constitutional Convention, in reference to Bayard v. Singleton, 1 N.C. (1 Mart.) 42 (1787), which had earlier occasioned debate in the North Carolina legislature. See 2 W. CROSSKEY, supra note 9, at 971-73.

187. Bayard v. Singleton, 1 N.C. (1 Mart.) 42 (1787); Trevett v. Weeden, Varnum 1 (R.I. 1787); Cases of the Judges, 8 Va. (4 Call) 135 (1788); Commonwealth v. Caton, 8 Va. (4 Call) 5 (1782).

188. Rutgers v. Waddington (N.Y. Mayor's Ct. 1784), reprinted in MAYOR's CouRT OF New YORK CitY, supra note 83, at 302, 323-26; Ham v. McClaws, 1 S.C.L. (1 Bay) 93 (1789). 
also held legislative acts unconstitutional in unreported cases. ${ }^{189}$ In most of these cases, advocates of the people's transcendent power to make law in their legislatures debated adherents to the older notions of the inherent rightness and immutability of law. In Rutgers $v$. Waddington, ${ }^{190}$ for example, the "supremacy of the Legislature . . . positively to enact a law" 191 was pitted against "the rights of human nature" and the "law of nature." 192 Similarly, in Trevett $v$. Weeden ${ }^{193}$ a Rhode Island act that penalized without jury trial anyone who refused to accept the state's paper currency was challenged as "contrary to the laws of nature" 194 and violative of the "fundamental right" of "trial by jury." 195

Until the 1790s, however, the line between believers in popular sovereignty and believers in supreme fixed principles was rarely so plainly drawn. One could still believe simultaneously in the people's power to make law and in the immutability of the principles underlying law. Although it appreciated and accepted popular lawmaking, the Revolutionary generation did not abandon older notions that law made by the people must not violate rights which Americans had proclaimed immutably theirs in the struggle with England. ${ }^{196}$ New and old ideas coexisted as the Revolutionary generation, believing in the people's inherent goodness, simply assumed that all laws made by the people would be consistent with fundamental rights.

During the 1790s, however, this ambivalent legal ideology proved merely transitory and diverged into two clearer, more coherent points of view. One sought to resolve all issues according to the

189. On the basis of a 1788 letter from J.B. Cutting to Thomas Jefferson, the Massachusetts case was initially identified as Brattle v. Hinckley (Sup. Jud. Ct., Worcester, Sept. Term, 1786). The court in that case, however, did not hold a legislative act unconstitutional, and none of the surviving records of the case indicate whether the court asserted its power of judicial review.

$\rightarrow$ Goodell, An Early Constitutional Case in Massachusetts, 7 HARv. L. REv. 415, 416 (1894). Professor Crosskey has accordingly described the Massachusetts case as one "which seems never to have occurred." 2 W. CROSSKEY, supra note 9, at 961-62. However, in Goddard v. Goddard (Sup. Jud. Ct., Suffolk, Feb. Term, 1789) the highest court of Massachusetts did, in fact, hold unconstitutional a legislative resolution reinstating a previously decided action in the court's docket. There were at least two unreported cases in New Hampshire in which the courts held void legislative acts changing the right to jury trial. These cases are discussed in 2 W. CrosskeY, supra note 9, at 968-71.

190. (N.Y. Mayor's Ct. 1784), reprinted in MAYOR's COURT OF New YORK CiTY, supra note 83 , at 302 .

191. Reprinted in MAYOR's COURT OF New YORK CITY, supra note 83, at 323.

192. Reprinted in MAYOR's COURT OF NEW YORK CITY, supra note 83, at 312.

193. J. Varnum, The Case, Trevett Against Weeden (Providence 1787).

194. Id. at 29.

195. Id. at 11 .

196. See G. Wood, supra note 91 , at 53-70, 291-305. 
will of the people and the other sought to resolve them according to fixed principles of law. The appearance of these competing ideologies was closely related to the division in American politics in the 1790s between Federalists, who generally viewed law as a reflection of fixed and transcendent principles, and Republicans, who considered it the embodiment of popular will.

Future Federalists and Republicans first divided over the seemingly trivial issue of the chief executive's title. ${ }^{197}$ Then, Hamilton's economic program, particularly the funding of the national debt and the creation of a national bank, stirred a more significant controversy. ${ }^{198}$ However, historians generally agree that the first truly national political organizations arose in the mid-1790s in response to the French Revolution ${ }^{199}$ and the signing of Jay's Treaty with Great Britain. ${ }^{200}$ These two events forced Americans to choose sides in the worldwide struggle between Britain and France that began in 1793, and for many the choice posed difficult ideological issues. Some Americans found themselves horrified by the excesses of the French Revolution during the early 1790 s and by its culmination in the Reign of Terror; others, while not approving of the death and violence, remained convinced that the French republican movement would ultimately warrant American sympathy.

The political divisions of the mid-1790's reflected domestic concerns as well. For example, the Federalists saw in Jefferson and the Republicans many of the threats to religion, to life, and to property that they found so horrifying in French revolutionaries. The election of 1800, they feared, would require voters to select either "GOD-AND A RELIGIOUS PRESIDENT; or impiously declare for JEFFERSON-AND NO GOD!!!'201 This widespread Federalist concern over Jefferson's lack of traditional religious belief ${ }^{202}$

197. For a discussion of this controversy, see J. Miller, The Federalist ERA 1789-1801, at 6-10 (1960).

198. See J. Charles, The Origins of the American Party System 83, 116-18 (1956); N. Cunningham, The Jeffersonian Republicans 8-9, $50-54$ (1957); J. Miller, supra note 197 , at $99-101$.

199. For a discussion of the national parties' reaction to the French Revolution, see J. Miller, supra note 197, at 127-39. R. BeEMAN, The Old Dominion AND the New Nation, $1788-1801$, at 119-37 (1972), discusses the reaction of Virginia.

200. See J. Charles, supra note 198, at 83, 116-18; R. Hofstadter, The Idea of A PARTY System 88-90 (1969); Goodman, The First American Party System, in The AMERICAN Party Systems 56, 74-75 (2d ed. W. Chambers \& W. Burnham 1975). See generally N. CuNNINGHAM, supra note 198 , at $54-66,77-85$. The literature on Jay's Treaty is vast. For a general overview, see J. MILLER, supra note 197, at 164-79.

201. Campaign placard, quoted in J. MILLER, supra note 197, at 265 n.34.

202. See Letter from A. Hamilton to J. Jay (May 7, 1800), reprinted in 8 THE WORKS OF Alexander Hamilton 549 (H. Lodge ed. 1886); W. Linn, Serious Considerations on the Election of a President Addressed to the Citizens of the United States 24 (1800); 
gained credence from the efforts of prominent elements in the Jeffersonian coalition in states such as Massachusetts and Virginia to pull down the religious orders those states had erected at their earliest settlements. ${ }^{203}$ For men who lived in an age which had had little experience with societies that had maintained their stability without the assistance of an established church, it was plausible to fear that if "the restraints of religion [were] once broken down, as they infallibly would be, by leaving the subject of public worship to the humors of the multitude,... we might well defy all human wisdom and power, to support and preserve order and government in the State[s]."204

If the Federalists were convinced that conferral of power upon Republicans would subvert morality and lead to violence and anarchy, the Republicans were equally convinced that, if allowed to retain power, the Federalists would subvert republican liberties and rule autocratically. Their fear of a Federalist conspiracy to pervert American liberties did not end in 1795; they most feared certain occurrences during the Adams Administration, ${ }^{205}$ such as the passage of the Alien and Sedition Acts, the imposition of a direct tax, and the establishment of a standing army and navy.

In short, clear-cut party divisions had emerged by the second half of the 1790s. On one side stood the Republicans, avowing "the doc-

Boston Repertory, March 9, 1804, quoted in J. BANNER, To THE HARTFORD Convention $1789-1815$, at 27 n.9 (1970).

203. For a discussion of Republicanism and the dissenting sects in Massachusetts, see $P$. Goodman, The Democratic-Republicans of MassachusetTs 86-96 (1964). See generally J. BANner, To the HARTFord Convention 1789-1815, at 197-215 (1970). But see id. at 210, stating that the dissenter/Republican alliance was "unstable" and "a triumph . . . of expediency over principle." Madison sought the support of Virginia Baptists and attempted to persuade eastern (Episcopalian) Virginians to join the dissenting sects' movement to force the sale of church glebe lands. The Republican aid in the cause was acknowledged in the election of 1800. See R. BEEMAN, supra note 199, at 93-95, 198-99.

204. Election sermon by Phillips Payson, quoted in I. BACKUS, Government and Liberty Described; and Ecclesiastical Tyranny Exposed, in IsAaC BaCKus on Church, STATE, AND CALVINISM 353 (W. McLoughlin ed. 1968).

205. The Federalists enacted a sedition law during that administration that "protect[ed] corrupt magistrates and public defaulters," Philadelphia Aurora, Oct. 14, 1800, while consigning "native Americans . . . to loathsome prisons for exercising the constitutional right of public enquiry." Joseph Bloomfield (chairman of the state Republican committee) to the People of New Jersey, (Sept. 30, 1800) (broadside, quoted in N. CuNNINGHAM, supra note 198, at 215). They also imposed "a direct tax, with heavy imposts," the Republicans charged, to "support . . . an army in time of peace" as well as "an expensive and ineffectual navy." Id. Finally, they enlisted "Priests and Judges . . . for political purposes, . . . equally polluting the holy altars of religion, and the seats of Justice," thereby threatening to institutionalize "[a]n established church, a religious test, and an order of Priesthood." Philadelphia Aurora, Oct. 14, 1800 . 
trine that mankind are capable of governing themselves,"206 and accused by their opponents of scheming "to introduce a new order of things as it repects morals and politics, social and civil duties."207 Opposite them stood the Federalists, claiming to preserve "that virtue [which] is the only permanent basis of a Republic," 208 and accused of attempting to restore monarchical government. Both parties were internally divided, ${ }^{209}$ of course, and not everyone adhered rigidly to his party's ideology. Some statesmen continued to believe that popular will did not inevitably conflict with fundamental standards of right and that law and governmental policy could accordingly reflect both. ${ }^{210}$ Nonetheless, when forced to choose, those who styled themselves Federalists generally proclaimed their preference for customary standards, while those who saw themselves as Republicans generally proclaimed their allegiance to the people's will.

These two competing political theories were deeply rooted in still fresh American political experiences; they responded to ardently felt political needs. Republicans in 1800 could look back upon a quarter-century of fervid political activity during which a majority of the people had transformed the American constitutional landscape. In light of this, Republicans could plausibly hope that the popular majority would secure revolutionary improvements in government through continued exertion. Federalists, on the other hand, looked back on a different governmental tradition. They focussed upon the workings of local government which, even after twenty-five years of revolutionary transformation, continued to function without falling under the arbitrary control of those in positions of power. Federalists recognized a tradition, that is, of government by customary norms whose validity all right-thinking men accepted. That such traditional government seemed under attack in 1800 and unable to resolve every political issue was not startling; eighteenth-century government-by-consensus had always been somewhat unstable and unequipped to resolve all problems. Nevertheless, it had succeeded 1792).

206. 6 WritingS of JAMES MAdison, supra note 181, at 118 (Letter to Randolph, Sept. 13,

207. Daggett, Sunbeams May Be Extracted from Cucumbers, but the Process Is Tedious [1799], in THE Rising Glory OF AMERICA 184 (G. Wood ed. 1971).

208. [Boston] New-England Palladium, April 1, 1806, at 2, col. 3, quoted in J. BANNER, supra note 203, at 26.

209. See R. Ellis, supra note 17, at 19, 53. See generally M. DAUER, supra note 54.

210. Among these people were John Jay, George Cabot, Thomas Truxton, Theodore Sedgwick, and William Cooper. See D. Fischer, The Revolution of AMERICAN ConserVATISM $1-17$ (1965). 
in many matters, and even its partial success offered hope to those in 1800 who dreaded government solely by majority will.

\section{Marshall's Offer of Compromise: The Separation of LAW FROM POLITICS}

The political struggle between Federalists and Republicans is centrally important to understanding John Marshall's constitutional jurisprudence. Marshall became Chief Justice at that struggle's height, just when Thomas Jefferson was finally elected President of the United States. Marshall, once a Federalist congressional leader and an active member of John Adams' administration, was immersed in the politics of the time. ${ }^{211}$ Hence, his views about the election of 1800 and the conflict leading to it merit discussion.

Marshall, of course, was a traditionalist who believed in natural rights that pre-existed government and legislation. In his clearest statement from the bench, an 1827 dissent in Ogden v. Saunders, ${ }^{212}$ Marshall argued that "the right to contract, and the obligations created by contract . . . exist anterior to, and independent of society [:] . . . [they] are, like many other natural rights, brought with man into society; and, although they may be controlled, are not given by human legislation."213 Similarly, in Fletcher v. Peck ${ }^{214}$ he spoke of "certain great principles of justice, whose authority is universally acknowledged . . . ."215 Earlier, he had affirmed to the Virginia convention that ratified the federal constitution his belief in the "observance" of "certain maxims_- . . certain fundamental principles, from which a free people ought never to depart."216

Marshall discussed the political divisions of the 1790s in later writings, notably his 1807 biography of Washington and an 1827 autobiographical letter to Justice Story. He "recollect[ed] the wild and enthusiastic democracy . . . of that [earlier] day . . . which brought annually into doubt principles which I thought most sound, [and] which proved that everything was afloat, and that we had no safe anchorage ground." 217 He recalled that "two great parties were

211. On Marshall's political career during the Washington and Adams administrations, see 2 A. BEVERIDGE, supra note 14.

212. 25 U.S. (12 Wheat.) 213 (1827).

213. 25 U.S. (12 Wheat.) at 345.

214. 10 U.S. (6 Cranch) 87 (1810).

215. 10 U.S. (6 Cranch) at 133.

216. 3 DeBATES, supra note 183 , at 222-23.

217. An Autobiographical Sketch by John Marshall 9, 10 (J. Adams ed. 1937). 
formed in every state." 218 One, which sought to remedy society's ills through legislation, produced "uncertainty with respect to measures of great importance to every member of the community, [and] . . . instability in principles which ought if possible to be rendered immutable . . .".219 The other, whose members were "the uniform friends of a regular administration of justice," supported "the principles of moral justice." 220 However, Marshall belonged to the moderate Adams wing of the Federalist Party, ${ }^{221}$ and, despite his conservatism and his belief in immutable principles of justice, he recognized better than his more extreme Federalist brethren that no American statesman could or should ignore the people's will. Thus, he told the Virginia ratification convention that he "idolize[d] democracy" as the "best means of protecting liberty."222 A decade later in 1798 he still believed that "the best rule for freemen . . . was . . . obedience to laws enacted by a majority" 223 and accordingly promised in his congressional campaign that he would, if "chosen to represent the district, obey the voice of . . . [his] constituents." 224

The goal, and the opportunity, for a moderate judge like Marshall was to reconcile the people's transcendent power with the law's immutable principles; that is, to reconcile the newer style of government by majority will with the older but still vital style of government by consensus. The need for reconciliation was especially urgent for Marshall because he found himself after 1800 at the head of a branch of government - the judiciary-which was being subjected for the first time in American history to a sustained attack not simply by transient mobs or occasional pamphleteers, but by duly elected representatives of the majority of the people in the legislature and the executive.

In the early years of Marshall's tenure on the bench, members of the Republican party warned that any attempt "of federalism to exalt the Judiciary over the Executive and Legislature, and to give that favorite department a political character \& influence . . . [would] terminate in the degradation and disgrace of the judiciary." 225 That

218. 5 J. Marshall, The Life of George Washington 85 (1807).

219. Id. at 87 .

220. Id. at 85 .

221. See M. DAUER, supra note 54 , at $163,236-37$.

222. 3 DEBATES, supra note 183 , at 222.

223. Address of the Minority: Journal of Virginia House of Delegates 88-90 (Dec. 1798), quoted in 2 A. BEVERIDGE, supra note 14, at 402.

224. Marshall's Answers to Freeholder's Questions (Sept. 20, 1798), reprinted in JoHN Marshall: Major Opinions and Other Writings 32 (J. Roche ed. 1967).

225. [Boston] Independent Chronicle, March 10, 1803. 
warning was expressed in several executive and legislative attempts to restrict the judiciary to a narrow, nonpolitical role, the most celebrated of which was the House of Representatives' impeachment of Justice Samuel Chase. ${ }^{226}$ Chase had acted in a partisan manner on several occasions, but an 1803 grand jury charge led directly to his impeachment. Chase had commented:

[T] he late alteration of the Federal Judiciary by the abolition of the office of the sixteen circuit judges, and the recent change in our State constitution by the establishing of universal suffrage, and the further alteration that is contemplated in our State judiciary (if adopted) will, in my judgment, take away all security for property and personal liberty. The independence of the national Judiciary is already shaken to its foundation, and the virtue of the people alone can restore it. . . . [O]ur republican constitution will sink into a mobocracy, the worst of all possible governments.

. . . [T]he modern doctrines by our late reformers, that all men in a state of society are entitled to enjoy equal liberty and equal rights, have brought this mighty mischief upon us and I fear that it will rapidly progress, until peace and order, freedom and property, shall be destroyed. 227

Although the Senate acquitted Chase, his impeachment nonetheless made both Chase and his Federalist colleagues on the bench more discreet and less partisan.

Early nineteenth-century state judges who stepped into political controversies likewise encountered difficulties with state legislatures dominated by Republicans. For example, when Judge Alexander Addison of Pennsylvania delivered a series of highly partisan grand jury charges and, with the aid of a Federalist colleague, prevented a Republican judge from addressing the jury at all, the Republican legislature impeached, convicted, and removed him from office. ${ }^{228}$ Similarly, when an informal conference of Georgia judges declared unconstitutional a politically sensitive grant of special relief to debtors and soldiers, the Georgia House of Representatives immediately prohibited future judicial conferences. $^{229}$ Finally, when the Massachusetts Supreme Judicial Court entered the political thicket in 1810 to strengthen the power of the established Congregational Church to raise taxes for religious purposes, ${ }^{230}$ the Republican legislature responded with the Religious Freedom Act of 1811, which not only

226. For descriptions of the impeachment, see R. ELLIS, supra note 17 , at 76-82; 1 C. WARREN, supra note 11 , at 269-95.

227. 8 AnNals of Cong. 674-75 (1804).

228. See R. Ellis, supra note 17, at 164-65.

229. See A. SAYE, supra note 98 , at 190-92.

230. See Barnes v. First Parish, 6 Mass. 401 (1810). 
reversed the court's decision but effectively abolished the religious establishment. ${ }^{231}$

The need of judges in the years after 1800 to stay clear of partisan controversy in order to retain their offices and preserve the judiciary's independence constituted a powerful impetus to a transformation of the judiciary's role. Marshall, for one, was aware of "[t]he consequences of refusing to carry . . . into effect" a law enacted by a popular majority. ${ }^{232}$ Nevertheless, the existence of partisan pressures cannot fully explain the substance of Marshall's constitutional jurisprudence. In his private correspondence, Marshall indicated that he would "disregard [those pressures] . . . when put in competition with what he ... [thought] his duty," ${ }^{233}$ and neither Marshall nor his colleagues on either the federal or the state bench took the easy course of invariably yielding to the majority's will. Early nineteenth-century judges, at times, continued to interpose the principles of law in the path of executing the people's will. Marshall and his contemporaries, in short, strove to reconcile popular will and legal principle, not to make legal principles subservient to the people's will.

They did this by distinguishing between the domain of law and the domain of politics. Indeed, the foundation of Marshall's constitutional jurisprudence is the distinction between political matters, to be resolved by the legislative and executive branches in the new majoritarian style, and legal matters, to be resolved by the judiciary in the government-by-consensus style that had prevailed in most eighteenth-century American courts. Marshall, of course, invented neither style, ${ }^{234}$ nor did he first apply the latter to the adjudicatory process. His creative act was to use the distinction between law and politics to circumscribe, however imperfectly, the extent to which the political, majoritarian style could engulf all government, as it was threatening in 1800 to do.

Merely announcing a line between law and politics does not, of course, fully differentiate the legal from the political. Hence, it is not surprising that Marshall's efforts to identify the line were hesitant,

231. See P. Goodman, supra note 203, at 162-66; W. Nelson, supra note 58, at 108-09.

232. See Letters of J. Marshall to W. Paterson (April 6, 9, and May 3, 1802), quoted in $1 \mathrm{C}$. WARREN, supra note 11, at 270.

233. Id.

234. For early intimations of the distinction between law and politics, $\rightarrow$ Hartog, The Public Law of a County Court: Judicial Government in Eighteenth Century Massachusetts, 20 AM. J. Legal Hist. $282\left(19^{\circ} \rightarrow\right.$ Rowe, Outlawry in Pennsylvania, 1782-1788 and the Achievement of an Independent State Judiciary, 20 AM. J. LEGAL HIST. 227 (1976); Wheeler, Extrajudicial Activities of the Early Supreme Court, 1973 SUP. CT. REv. 123. 
incomplete, and sometimes confused. Nonetheless, despite the difficulty of the task, Marshall and his fellow judges persistently kept in mind the desirability of adjudicating at least some matters by a nonmajoritarian standard and thereby restraining "the capricious will of the rulers of the day." 235 Their difficulty came in articulating consistent and precise criteria for identifying matters appropriately decided by the legal method. Judges spoke about individual rights, ${ }^{236}$ private rights, ${ }^{237}$ natural rights, ${ }^{238}$ and rights created by express constitutional restrictions, ${ }^{239}$ but they never agreed upon a single, unambiguous criterion of when a right was such that its holder was entitled to legal protection against political encroachment. The main thesis of this essay, to be elaborated below, is that early nineteenth-century judges gave effect to express constitutional restrictions and various kinds of rights only when they sensed, however vaguely, that such action would be supported by a widespread consensus. They thereby reverted to the governance technique of their eighteenth-century predecessors, though with one difference: Marshall and his contemporaries sought with some but not total success to reduce the areas of consensus they observed to an analytically rigorous category of rights subject to legal protection. As we examine the decisions of Marshall and other early nineteenth-century judges, both the attempt to create this analytical category and the rooting of the category in an observed consensus should be kept in mind.

\section{A. The Initial Elaboration of the Law-Politics Distinction: Marbury v. Madison and Stuart v. Laird}

Marbury v. Madison ${ }^{240}$ was the first instance after the 1800 election upon which Marshall and the other Federalist justices publicly

235. Boston Gazette, Feb. 13, 1806, at 1, col. 2 (emphasis original).

236. Marbury v. Madison, 5 U.S. (1 Cranch) 137, 166 (1803); see text at note 250 infra.

237. See Fletcher v. Peck, 10 U.S. (6 Cranch) 87 (1810); Gardner v. Trustees of the Village of Newburgh, 2 Johns. Ch. 162 (N.Y. 1816); text at notes 264-73 infra. The law of private and individual rights to which recourse was had in constitutional cases is not entirely clear, since that law was in a state of great flux in the opening decades of the nineteenth century. See generally M. HoRwITZ, supra note 120; W. NeLSON, supra note 58, at 117-64. This suggests that, while early nineteenth-century Americans may have been in rough agreement about the importance of protecting private, individual rights, see text at note 273 infra, that rough agreement may have existed only because the specifics that such protection would entail had not been worked out.

238. See Ogden v. Saunders, 25 U.S. (12 Wheat.) 213, 345 (1827) (Marshall, C.J., dissenting); text at note 212 supra.

239. See Trustees of Dartmouth College v. Woodward, 17 U.S. (4 Wheat.) 518 (1819); United States v. The William, 28 F. Cas. 614 (C.C.D. Mass. 1808) (No. 16,700); White v. Kendrick, 3 S.C.L. (1 Brev.) 469 (1805); see text at note 274 infra.

240. 5 U.S. (1 Cranch) 137 (1803). 
addressed the task of reconciling popular will and immutable principle. ${ }^{241}$ As such, it was central to the process of differentiating law and politics. In that familiar portion of the opinion which asserts the power of judicial review, Marshall reiterated his belief in "the fundamental principles" of law that were "designed to be permanent."242 $\mathrm{He}$ did not assert, however, that these principles acquired their permanence from any inherent strength, but rather from the "original right" of the people "to establish, for their future government, such principles as, in their opinion, shall most conduce to their own happiness." 243 Thus, Marshall did not reconcile the people's power with human rights by arguing that rights embodied in the Constitution had any ultimate moral or historical verity. At no point in the Marbury opinion did Marshall invoke the language of natural rights, nor did he rely on precedent or other historical authority. In fact, he cited only one case in his entire opinion. Marshall instead evoked the Revolutionary generation's assumption that the people, exercising their power to create government, had incorporated basic and generally agreed upon principles of right into their Constitution. ${ }^{244}$ This approach was not new, of course; Federalist No. $78^{245}$ had formulated it much earlier, and several state judicial review cases had reiterated it during the 1790s. ${ }^{246}$ Indeed, Marshall himself had written during the 1780s of certain "maxims of democracy," which included "[a] strict observance of justice and public faith, and a steady adherence to virtue." 247

While Marshall's assumption that the Constitution embodied the people's rights eliminated the conflict between fixed principle and popular power at the level of theory, it did little to prevent actual conflicts. Such conflicts arose when interest groups like religious dissenters sought legislatively to mold a society they thought more just and thereupon clashed with courts determined to preserve traditional social values. We now tend to ignore the portions of Marbury in which Marshall struggled for a standard that would minimize ac-

241. In Congress' first session after Jefferson's inauguration, it enacted legislation that postponed the Supreme Court's two 1802 sessions until February 1803. See Act of April 29, 1802, 2 Stat. 156; 1 C. WARren, supra note 11, at 222-23. Consequently, the Court did not meet between 1801 and 1803. In 1801, significant cases like Marbury and Stuart v. Laird, 5 U.S. (1 Cranch) 299 (1803), were not yet ready for decision.

242. 5 U.S. (1 Cranch) at 176-77.

243. 5 U.S. (1 Cranch) at 176.

244. See text at notes 213-16 supra.

245. The Federalist No. 78, at 491-94 (A. Hamilton) (B. Wright ed. 1961).

246. See State v. — 2 N.C. (1 Hayw.) 38 (1794); Kamper v. Hawkins, 3 Va. (1 Brock. \& H.) 20 (1793). See also VanHorne's Lessee v. Dorrance, 2 U.S. (2 Dall.) 304 (1795).

247. 3 Debates, supra note 183, at 222. 
tual conflict, but the Marshall Court probably considered those the most important parts. Indeed, from the perspective of the Court's Federalist Justices, the primary issue in Marbury was not judicial review, but whether the executive could defy the law.

When summoned before the Court in the preliminary stages of the case, Department of State officers had claimed not only to be under no obligation to deliver Marbury's commission, but also to be privileged, by virtue of their executive status, not to testify about any transactions concerning the commission. Marshall recognized this as a potentially far-reaching claim, for if the government asserted such a privilege in matters involving land patents, which Marshall thought analogous to commissions for office, ${ }^{248}$ it would cloud the title to much of the land west of the Appalachians. Unfounded fears had intensified the political divisions of 1800 , and, whatever the truth may have been, the Federalist Court doubtless feared that Thomas Jefferson's new administration might claim to be above the law in these matters as well as others. Marshall's real difficulty was that he, unlike more extreme Federalists, could not summarily reject the claim of executive privilege, for as he had once told his constituents, he believed that the people, and hence their agents in the political branches of government, must sometimes be free to act unbound by fixed legal principles. ${ }^{249}$ Accordingly his central task in Marbury was to specify when law bound the political branches and when it did not. To do so, he and the Court distinguished between political matters, such as foreign policy, as to which the legislature and executive were accountable only to the electorate, and matters of individual rights, which the courts would protect by adhering to fixed principles. In Marshall's own words, "political" subjects "respect[ed] the nation, not individual rights" and were governed by a political branch whose decisions were "never . . . examinable by the

248. On the early nineteenth-century analogy of officeholding to other kinds of property, see W. Nelson, supra note 58, at 125 . Marbury's counsel specifically argued that, if an individual were "entitled to a patent for lands purchased of the United States" and the Secretary of State refused "to affix the great seal to the patent," the individual should "have a mandamus to compel him." "In this respect," he argued, "there is no difference between a patent for lands, and the commission of a judicial officer." 5 U.S. (1 Cranch) at 150 (emphasis original). In his opinion for the Court, Marshall concluded that Marbury's commission "conferred legal rights," 5 U.S. (1 Cranch) at 162, and then hypothesized a case in which a "purchaser [of land], on paying his purchase-money, becomes completely entitled to the property purchased" but the Secretary of State chose to "withhold" his "patent," 5 U.S. (1 Cranch) at 165. Marshall asked, "[C]an it be imagined that the law furnishes to the injured person no remedy?" 5 U.S. (1 Cranch) at 165 , and used this hypothetical to conclude that "where a specific duty is assigned [to a cabinet officer] by law, and individual rights depend on the performance of that duty, it seems equally clear that the individual who considers himself injured, has a right to resort to the laws of his country for a remedy." 5 U.S. (1 Cranch) at 166.

249. See text at notes 222-24 supra. 
courts" but "only politically examinable." In contrast stood "the rights of individuals," respecting which every officer of government was "amenable to the laws for his conduct; and [could not] at his discretion sport away. . . vested rights . . . ."250

That distinction runs throughout the Court's opinion and is essential to our understanding of the case. It explains, for example, how Marshall could plausibly believe that judicial review involved not an exercise of political discretion by the Court, but merely a mechanical juxtaposing of statute with Constitution to see if they conflicted. When the Court could resolve a case according to seemingly fixed principles rather than transient policies, Marshall believed judicial review fell on the law side of the distinction; it was a judicial protection of immutable, individual rights. However, a case that required the Court to choose among transient policies or otherwise to exercise political discretion was not in Marshall's estimation an appropriate case for judicial review.

Similarly, it was the distinction between matters of political discretion and matters of legal right that required the Court to reject Marbury's argument about the scope of the Supreme Court's jurisdiction to award mandamus. It is noteworthy that Marbury's counsel did not press the argument that by granting mandamus in a suit commenced before it the Supreme Court exercised its original jurisdiction; he almost conceded that Congress could not give the Court jurisdiction over original matters not specified in the Constitution. ${ }^{251}$ Instead, he mainly argued that the Court exercised appellate jurisdiction when issuing mandamus in a proceeding commenced before it. According to the thrust of his argument, which flowed from an accurate reading of Federalist $N o$. 81, "the word 'appellate' [was] not to be taken in its technical sense, . . . but in its broadest sense, in which it denotes nothing more than the power of one tribunal" to have "by reason of its supremacy . . . the superintendence of . . . inferior tribunals and officers, whether judicial or ministerial." 252 In 1803 , when the concept of appeal had not yet assumed its relatively

250. 5 U.S. (1 Cranch) at 166.

251. Marbury's counsel, Charles Lee, argued only that "Congress is not restrained from conferring original jurisdiction in other cases than those mentioned in the constitution," 5 U.S. (1 Cranch) at 148, and made no effort to pursue the argument as Marshall did in his opinion. His failure to pursue the argument that the Court could issue mandamus as a matter of original jurisdiction is not, however, surprising, since Lee was also counsel in Stuart v. Laird, 5 U.S. (1 Cranch) 299 (1803), see text at note 256 infra, decided six days after Marbury, where he argued that "[n]o act of congress can extend the original jurisdiction of the supreme court beyond the bounds limited by the constitution." 5 U.S. (1 Cranch) at 305.

252. 5 U.S. (1 Cranch) at 147 , 148. See The Federalist No. 81 , at 512 (A. Hamilton) (B. Wright ed. 1961). 
narrow and precise modern meaning, ${ }^{253}$ that argument was plausible, and a Court anxious to grant Marbury relief could easily have accepted it. However, that position would have contradicted the opinion's main point, for it would have frequently led the Court to "revis[e] and correct the proceedings in a cause already instituted" 254 in the executive branch and might thereby have brought before the Court all the issues, both of law and of fact, that the executive branch had previously considered. ${ }^{255}$ Such review might have continually presented the Court with political questions of executive motive. To avoid this danger and to insure that the Court serve as the purely legal institution he envisioned, Marshall had to consider a mandamus against officials, as distinguished from a mandamus against lower court judges, as an original action in which the lower court could confine the action's scope to properly legal rather than political matters. Thus, he had to reject the claim that mandamus was a direct appeal from the executive to the Supreme Court.

The distinction between law and politics outlined in Marbury gained force six days later from the Court's disposition of another case questioning the constitutionality of an act of Congress. Stuart $v$. Laird $^{256}$ passed upon the Republicans' Judiciary Act of 1802,257 which repealed the Federalists' Judiciary Act of 1801.258 Federalists had contended in Congress that the 1802 Act was unconstitutional because it deprived judges appointed under the 1801 Act of the lifetime tenure guaranteed by article III, section 1.259 The 1802 Act was also said to be unconstitutional because it required Supreme Court Justices to sit as trial judges in circuit courts, thereby conferring an original jurisdiction which, the argument contended, only the Constitution could confer. ${ }^{260}$ Marbury, we ought to recall, had been decided on an almost identical ground.

253. $S \rightarrow$ Surrency, The Development of the Appellate Function: The Pennsylvania Experience, 20 AM. J. Legal Hist. 173 (1976).

254. 5 U.S. (1 Cranch) at 175.

255. Such, at least, is the main thrust of counsel's argument for Marbury. See 5 U.S. (1 Cranch) at 147-48.

256. 5 U.S. (1 Cranch) 299 (1803).

257. Ch. 8, 2 Stat. 132 (1802).

258. Ch. 4, 2 Stat. 89 (1802).

259. See 1 AnNals of Cong. 75 (Gales \& Seaton eds. 1802) (remarks of Sen. Olcott); id. at 119 (remarks of Sen. White); id. at 632 (remarks of Rep. Bayard).

260. See 1 Annals of Cong. 39 (Gales \& Seaton eds. 1802) (remarks of Sen. Morris); id. at 78-79 (remarks of Sen. Morris); id. at 675 (remarks of Rep. Huger). Of course, there were also arguments that the repeal of the 1801 Act would impair the judiciary's independence. See, e.g., id. at 131-32 (remarks of Sen. Chipman); id. at 730 (remarks of Rep. Goddard). Marshall himself indicated in private correspondence that if presented with the question de novo, he would conclude that Supreme Court justices could not sit on lower courts. But he added that the Court's previous acquiescence in circuit duties, as well as the opinions of the majority of the other justices, inclined him "to execute the law" of 1802 that imposed circuit 
Nonetheless, the Marshall Court sustained the 1802 Act. The apparent inconsistency between Marbury and Stuart, however, masks a deeper consistency in the Court's approach. Significantly, the Court in Stuart never faced the contention that would have most troubled it: that the 1802 Act unconstitutionally deprived judges of office. That contention would have involved issues of legally enforceable private rights, ${ }^{261}$ but it was not even raised, for Stuart was not one of the judges deprived of office; he was merely a litigant objecting to the transfer of his case from a court constituted under the 1801 Act to a court constituted under the 1802 Act. His complaint raised no issue of fundamental private rights, only issues of Congress's political power to organize the lower federal courts.

There were two such issues. First, could Congress require a litigant to pursue his remedies in one court rather than another? As Marshall would suggest twenty-four years later in Ogden $v$. Saunders, ${ }^{262}$ the legislature clearly could control remedies. Second, could Congress require Supreme Court justices to ride circuit and thereby exercise an original jurisdiction not enumerated in the Constitution? Marbury had decided, of course, that Congress could not expand the Supreme Court's original jurisdiction, but Stuart could be distinguished from Marbury, in that the 1802 Judiciary Act required individual justices, not the full Court, to exercise original jurisdiction. Further, as Justice Paterson explained for the unanimous Court, the 1802 Act merely confirmed "practice and acquiescence . . . commencing with the organization of the judicial system." Such practice and acquiescence "afford[ed] an irresistible answer" to the claim of unconstitutionality; it was a "practical exposition . . . too strong and obstinate to be shaken or controlled," and "indeed fixed the construction" of the Constitution. That the justices had performed the circuit duties the 1789 Judiciary Act had imposed put "the question . . . at rest." 263 In Marbury, on the other hand, no strong public sentiment, precedent, or established practice stood in the way of holding that the Constitution's language prohibited the issuance of mandamus as a matter of original jurisdiction.

duties. See Letters from J. Marshall to W. Paterson (April 6, 9, and May 3, 1802), quoted in 1 C. WARREN, supra note 11 , at 269-71.

261. See note 248 supra. The statements of Marshall quoted in note 248 from Marbury suggest that the Court would have granted relief to a judge who had been deprived of office unless the Court was able, as it had been in Marbury, to find a procedural ground for denying relief.

262. 25 U.S. (12 Wheat.) 213,353 (1827) (dissenting opinion).

263. 5 U.S. (1 Cranch) 299, 309 (1803). 
But a more fundamental fact distinguished Marbury from Stuart. By invalidating the Republican-sponsored Judiciary Act of 1802, the Marshall Court would have embroiled itself in a political contest with Congress and the President which it might not have survived. If the Court was to withdraw from politics, as Marshall had said in Marbury it would, it had to capitulate to legislative judgments upon such politically controversial issues as the constitutionality of the 1802 Act. It therefore sustained the act. By contrast, the only way to avoid the politics behind Marbury had been to construe the Constitution in a way to which few would object and thereby invalidate section 13 of the 1789 Judiciary Act. To have issued a writ of mandamus to James Madison as Secretary of State would have thrust the Court into a political crisis. The Court's only other option-to hold on substantive grounds that Marbury had no right to the mandamus - would have denied some individuals access to the courts to enforce their legal rights. In short, to maintain Marshall's compromise - that courts would protect legal rights but refrain from adjudicating political questions - the Court had to decide both Marbury and Stuart as it did.

\section{B. Marshall and the Protection of Legal Rights}

Marshall continued to distinguish between politics and law in other major constitutional opinions. The next case in which he did so was Fletcher v. Peck, ${ }^{264}$ which involved the validity of two Georgia acts. The first act had granted land to individuals who subsequently passed title to the plaintiff Fletcher, a bona fide purchaser for value; the second had repealed the first on the ground that the first had been enacted because several state legislators had been bribed. The Court was asked to invalidate the first act because of the bribery, but Marshall declined to do so because "the principle by which judicial interference would be regulated . . . [could] not [be] clearly discerned." 265 The validity of the first act was not properly a legal question because the Court could find no fixed, uncontroversial standards by which to resolve it. On the other hand, Marshall readily voided the second act, because it violated "certain great principles of justice, whose authority is universally acknowledged." 266 The issue in Fletcher v. Peck was, he observed, "in its nature, a question of title"267-more specifically, a question of legislative power to revoke

264. 10 U.S. (6 Cranch) 87 (1810).

265. 10 U.S. (6 Cranch) at 130.

266. 10 U.S. (6 Cranch) at 133.

267. 10 U.S. (6 Cranch) at 133. 
a grant of land by claiming that the grant had been fraudulently obtained. According to Marshall, the law of land title was clear: "If a suit be brought to set aside a conveyance obtained by fraud, and the fraud be clearly proved, the conveyance will be set aside, as between the parties; but the rights of third persons, who are purchasers without notice, for a valuable consideration, cannot be disregarded." 268 For the Georgia legislature to feel "itself absolved from those rules of property which are common to all the citizens of the United States, and from those principles of equity which are acknowledged in all our courts" was for it to act on the authority of "its power alone." The same power could be used to "divest any other individual of his lands, if it shall be the will of the legislature so to exert it." 269

In sum, the Court had to invalidate one of two Georgia statutes in Fletcher v. Peck. It did not, however, undertake what Marshall saw as the essentially political task of identifying which of a legislator's motives for supporting a bill were legitimate. Rather, it appealed to what seemed a fixed legal principle incorporated in the contract clause of the Constitution and relied upon by the vast majority of American people: that a legislature could not take back land which it had granted away.

This disposition of Fletcher v. Peck defused a heated political controversy that had long been raging in Georgia and in the Congress of the United States 270 and resolved the case with little negative comment. ${ }^{271}$ In my view, the Court enjoyed this success because it avoided the issue of fraud in the original legislative grant through which Fletcher claimed title, ${ }^{272}$ a volatile issue that would have provoked charges of personal wrongdoing. Instead, the Court passed upon the scope of state power to seize private property-an issue which was not yet politically divisive and which could be answered by invoking widely shared beliefs about individual rights in a republican state. ${ }^{273}$

268. 10 U.S. (6 Cranch) at 133.

269. 10 U.S. (6 Cranch) at 134.

270. See generally C. MCGrath, Yazoo 1-19 (1966).

271. Id. at $85-88$.

272. Id. at 7-19.

273. See L. Hartz, Economic Policy and Democratic Thought 22-23, 62-64 (1948); C. MCGrath, supra note 270 , at $77-84$. For a state case, which similarly defused a political controversy, see State v. Parkhurst, 9 N.J.L. 427 (1802), a New Jersey case concerning a United States Senator's right to be a senator and a county clerk simultaneously. The political issue-which of two political factions would control an important local office-was clear, but the court ably avoided it and deduced a holding from accepted republican principles. Consequently, the case did not permanently favor one faction or propel the judiciary into the funda- 
One can read Trustees of Dartmouth College v. Woodward ${ }^{274}$ as a variation on the same theme. The dispute arose when the New Hampshire legislature attempted to revoke not a grant of land but a grant of corporate governing privileges that had been made to selfperpetuating trustees who had received land and money from other individuals. It came to the Supreme Court after a lengthy, bitter political controversy in the state. ${ }^{275}$ The Court voided the repeal act because it constituted a taking of vested rights protected by the contract clause. Again Marshall appealed to shared general principles to support his holding, noting that "[t]he parties in this case differ less on general principles, . . . than on the application of those principles to this case." 276 The parties agreed that "[i]f the act of incorporation be a grant of political power . . . or if the State of New Hampshire, as a government, be alone interested in its transactions, the subject [was] one in which the legislature of the State may act according to its own judgment . . . ."277 "But if this be a private eleemosynary institution, endowed with a capacity to take property for objects unconnected with government, whose funds are bestowed by individuals on the faith of the charter," then the legislature was restrained by the "limitation of its power imposed by the constitution of the United States." 278 After painstakingly analyzing the facts, Marshall found Dartmouth College a private institution whose property the state accordingly could not take. This disposition of Dartmouth College, like the Court's disposition of Fletcher v. Peck, aroused little criticism from contemporaries. ${ }^{279}$

\section{Marshall and Political Questions}

Marshall enjoyed less success in defusing controversy in cases that did not involve individual rights unquestioned by most of his contemporaries. Perhaps the two most controversial cases in which the Marshall Court invalidated state legislation were McCulloch $v$. Maryland ${ }^{280}$ and Gibbons v. Ogden. ${ }^{281}$ In both cases, Marshall appealed, as usual, to "proposition[s]" commanding "the universal as-

mental social issues underlying the factional split; it left the factions free to contest those issues in the legislature and at the polls.

274. 17 U.S. (4 Wheat.) 518 (1819).

275. See 4 A. BEVERIDGE, supra note 14, at 226-36.

276. 17 U.S. (4 Wheat.) at 629.

277. 17 U.S. (4 Wheat.) at 629-30.

278. 17 U.S. (4 Wheat.) at 630.

279. See l C. WARREN, supra note 11 , at 487-90.

280. 17 U.S. (4 Wheat.) 316 (1819).

281. 22 U.S. (9 Wheat.) 1 (1824). 
sent of mankind"282 and to "principle[s]" that were "universally admitted" 283 or upon which "all America [was] united." 284 But he ultimately recognized that he could not address the core issue in each case - the scope of congressional power under the Commerce Clause and the Necessary and Proper Clause-as he addressed questions about private legal rights.

For example, he described the controlling issue in McCulloch-whether the creation of a national bank was a necessary and proper exercise of Congress' power over the currency-as "a doubtful question, one on which human reason may pause, and the human judgment be suspended, [and] in the decision of which the great principles of liberty are not concerned ...."285 When faced with such a question, Marshall concluded, the Court "must allow to the national legislature that discretion . . . which will enable that body to perform the high duties assigned to it, in the manner most beneficial to the people." 286 To interfere with that discretion "would be to pass the line which circumscribes the judicial department, and to tread on legislative ground."287 Marshall immediately "disclaim[ed] all pretensions to such a power." 288 In short, he argued that the $M c C$ Clloch conflict did not pit the legislature against an individual vested with universally sanctified rights; hence he knew that the conflict was not ultimately susceptible to a legal resolution. On the contrary, Marshall contended that this conflict involved questions of power rather than right and that the courts could only acquiesce in the will of the political branches upon such questions. ${ }^{289}$

Yielding in $\mathrm{McC}$ Culloch to the political branches did not defuse controversy as it had in Fletcher and Dartmouth College, probably because the distinction between law and politics that was so central to Marshall's constitutional jurisprudence was directed toward a different issue than $M c$ Culloch's core issue. While that distinction was not irrelevant to the decision of $M c$ Culloch, the more important line

282. 17 U.S. (4 Wheat.) at 405.

283. 17 U.S. (4 Wheat.) at 405.

284. 22 U.S. (9 Wheat.) at 191.

285. 17 U.S. (4 Wheat.) at 401.

286. 17 U.S. (4 Wheat.) at 421.

287. 17 U.S. (4 Wheat.) at 423.

288. 17 U.S. (4 Wheat.) at 423.

289. Of course, some question existed whether the Supreme Court should defer to the federal legislative branch or to a state legislature. Although this issue was not uncontroverted at the time of $M c$ Culloch, the Supremacy Clause seemed to dictate deference to Congress rather than to a state whenever Congress and the states disagreed about the boundary between their respective powers. 
to be drawn was that separating the sphere of federal from the sphere of state power. Marshall, who perhaps intuited what the Civil War ultimately proved-that the scope of federal jurisdiction is a matter of power, not right-refused to draw that line, however, and left it instead to Congress. As a practical matter, this decision denied that legal limits concerning the scope of national power existed and thereby sparked controversy and opposition. But, as Marshall himself implied, ${ }^{290}$ any attempt by the Court to determine for itself the precise limits of national power would have aroused even more controversy, and the fact is that Marshall's technique of leaving issues of national power to the political process worked adequately for nearly four decades until, in Dred Scott, ${ }^{291}$ the Court unsuccessfully began to pursue a different approach.

In Gibbons v. Ogden 292 as in McCulloch, Marshall withheld giving a definitive construction of the Commerce Clause, insisting merely that it not be read in a way that would "leave it a magnificent structure, indeed, to look at, but totally unfit for use."293 Unlike Justice Johnson, who would have invalidated the New York-granted steamboat monopoly on the theory that the Commerce Clause in and of itself prohibited "all invidious and partial restraints" on commerce, ${ }^{294}$ Chief Justice Marshall merely wanted to insure that Congress could either authorize or eliminate such restraints. In language reminiscent of Marbury $v$. Madison, ${ }^{295}$ Marshall wrote that in political "instances, as that, for example, of declaring war," the people's only reliable protections from abuse were "[t]he wisdom and the discretion of Congress, their identity with the people, and the influence which their constituents possess at elections . . . ."296 Marshall invalidated the New York monopoly only because he found it inconsistent with a federal law permitting all licensed vessels to engage in coastal trade.

In a third case, Sturges $v$. Crowninshield, ${ }^{297}$ Marshall engaged in similar reasoning to uphold in part the constitutionality of state bankruptcy and insolvency legislation. The Court shied away from

290. See John Marshall's Defense of McCulloch v. Maryland 190-91 (G. Gunther ed. 1969).

291. Dred Scott v. Sandford, 60 U.S. (19 How.) 393 (1857).

292. 22 U.S. (9 Wheat.) 1 (1824).

293. 22 U.S. ( 9 Wheat.) at 222.

294. 22 U.S. ( 9 Wheat.) at 231 (concurring opinion).

295. 5 U.S. (1 Cranch) 137 (1803); see text at note 250 supra.

296. 22 U.S. (9 Wheat.) at 197.

297. 17 U.S. (4 Wheat.) 122 (1819). 
"the delicate inquiry" 298 whether Congress' power to enact bankruptcy laws preempted all state legislation, and held that the states, without doubt, could still pass insolvency laws. Noting the "difficulty of discriminating with any accuracy between insolvent and bankrupt laws," Marshall concluded that any line demarcating federal and state power in the field "must be in a great degree arbitrary" and that the subject was therefore "one on which the Legislature may exercise an extensive discretion." 299 Since no federal bankruptcy legislation was then in force, Marshall deferred to the state political process. He added, however, that no legislature could impair vested private rights, and accordingly invalidated the challenged state legislation insofar as it discharged contractual obligations made prior to its enactment.

In short, analysis of the early cases in which the structure of Marshall's constitutional jurisprudence was set suggests that Marshall gave meaning to the law-politics distinction by treating matters as legal only when two conditions were met. First, a matter had to concern individual rights. But even then Marshall would not interpose judicial power in the path of a majority's will unless he felt confident, as in Fletcher and Dartmouth College, that such a legal disposition of a case would command wide public support. If both these conditions were not met, then Marshall would defer to the political branches of government-generally, as in Stuart, McCulloch, and Gibbons, to Congress, if federal legislation applied to the case, but otherwise, as in Sturges, to the states. Only once, in Marbury, did he set an act of Congress aside, and there he gave practical effect to the executive's interest in upholding its policies toward the midnight judges - an interest which far transcended Congress's concern for the policies underlying Section 13 of the Judiciary Act.

\section{The Law-Politics Distinction in the Lower Courts}

Marshall was not the only judge to employ the emerging distinction between law and politics in constitutional adjudication. One like-minded judge was John Davis, the federal district judge for the District of Massachusetts. In United States $v$. The William, ${ }^{300}$ Judge Davis pondered the constitutionality of congressional legislation effectuating Jefferson's embargo of 1807. Despite his Federalist leanings and the sympathy for mercantile interests he expressed in his

298. 17 U.S. (4 Wheat.) at 196.

299. 17 U.S. (4 Wheat.) at 195.

300. 28 F. Cas. 614 (C.C.D. Mass. 1808) (No. 16,700). 
opinion, Davis held the legislation constitutional. His opinion primarily discussed judicial review and stated his belief in the court's power to invalidate acts of Congress. He held, however, that the judiciary's power extended only to cases involving "[a]ffirmative provisions and express restrictions, contained in the constitution, [which were] sufficiently definite to render decisions . . . satisfactory." 301 In that way, judicial review would be limited to cases "in which the superior, commanding, will of the people . . . would be clearly and peremptorily expressed." 302 Davis accordingly refused to exercise judicial review to strike down Jefferson's embargo, writing:

To extend this censorial power further, and especially to extend it to the degree, contended for in the objections to the act now under consideration, would be found extremely difficult, if not impracticable, in execution. To determine where the legitimate exercise of discretion ends, and usurpation begins, would be a task most delicate and arduous. It would, in many instances, be extremely difficult to settle it, even in a single body. It would be much more so, if to be adjusted by two independent bodies, especially if those bodies, from the nature of their constitution, must proceed by different rules. Before a court can determine, whether a given act of congress, bearing relation to a power with which it is vested, be a legitimate exercise of that power, or transcend it, the degree of legislative discretion, admissible in the case, must first be determined. Legal discretion is limited. It is thus defined by lord Coke, "Discretio est discernere, per legem, quid sit justum." Political discretion has a far wider range. It embraces, combines and considers, all circumstances, events and projects, foreign or domestick, that can affect the national interests. Legal discretion has not the means of ascertaining the grounds, on which political discretion may have proceeded. It seems admitted, that necessity might justify the acts in question. But how shall legal discussion determine, that political discretion, surveying the vast concerns committed to its trust, and the movements of conflicting nations, has not perceived such necessity to exist? Considerations of this nature have induced a doubt of the competency, or constitutional authority of the court, to decide an act invalid, in a case of this description. ${ }^{303}$

Since Congress arguably had enacted the embargo pursuant to its powers to regulate foreign commerce and to wage war, since those powers concededly authorized at least some interdictions of trade, and since the propriety of Jefferson's interdiction depended at least partly on political judgment, Davis decided, much as Marshall had in Marbury, that the judiciary could not pass upon the embargo's validity.

301. $28 \mathrm{~F}$. Cas. at 620.

302. $28 \mathrm{~F}$. Cas. at 620 .

303. $28 \mathrm{~F}$. Cas. at 620. 
Eight years later, the Supreme Judicial Court of Massachusetts was asked in Adams v. Howe ${ }^{304}$ to determine the constitutionality of the Religious Freedom Act of 1811, which effectively abolished the Congregationalist religious establishment in the state. Chief Justice Isaac Parker, politically a moderate Federalist, wrote the unanimous affirming opinion. Parker, like Marshall and Davis, did not doubt the judiciary's power to declare unconstitutional any legislation "diminishing . . . the rights of the citizen . . .."305 Nor did Parker doubt the "evil tendency or inexpediency" of the legislation or "the injury to public morals and religion" it might cause. ${ }^{306}$ Nonetheless, because invalidating the act would require the court to exercise political discretion-an impermissible form of judicial decision-making-Parker refused to do so. He explained:

[T] he mode . . . of executing the will of the people, in this particular, is left entirely to the legislature: and although laws may be passed, which have a contrary tendency, and which, in their consequences, may injure, instead of promoting, the public worship; yet the legislature is to judge: and even their erroneous construction of the design of the people, as expressed in the said declaration, must have legal effect, so far as they are not manifestly repugnant to the principles of the constitution.

This being the character of the legislative power on this all important subject, we are at a loss to conceive how it can be restrained. . . . Great responsibility rests upon the legislature, and also upon the people in delegating power to those, who have almost unlimited authority. If they, with a view to secure the rights of conscience, pass laws within the letter of the constitution, which may have a tendency injuriously to affect the regular public worship, it is not for the judiciary power to control their course. ${ }^{307}$

Almost identical to Adams v. Howe in facts and result was an 1804 Virginia case, Turpin v. Locket, ${ }^{308}$ in which an equally divided court of appeals affirmed a decree of Virginia's chancellor which had sustained the constitutionality of legislation depriving the formerly established Protestant Episcopal Church of its title to certain glebe lands. Two judges, St. George Tucker and Spencer Roane, wrote opinions affirming the decree below. Although both were closely associated with President Jefferson, they adopted a position remarkably similar to Marshall's in Marbury. Tucker asserted that if the legislature had been "impolitic, and unadvised," it was "competent

304. 14 Mass. 340 (1817).

305. 14 Mass. at 348.

306. 14 Mass. at 344, 345.

307. 14 Mass. at 348.

308. 10 Va. (6 Call) 113 (1804). 
to amend, or repeal its . . . act, provided it do not annul, or avoid any private right, which may have been legally acquired by any individual in his natural capacity, under such act . . . ." In Tucker's view, the legislature could act freely in matters "having . . . relation to the community at large" rather than to private rights; on the other hand, "a court of justice [could] only pronounce [an] act void so far as it contain[ed] any thing, which the constitution of the commonwealth prohibits the grant of." 309 Spencer Roane elaborated the distinction between public matters amenable to political solutions and private rights protected by law. Roane wrote that he would

not be among those, who assert a right in the government, or even in the people, to violate private rights, and perpetrate injustice. The just end and object of all governments, and all revolutions, reprobate this idea. I trust I shall not be more tardy, than those who are more loud and clamorous, to respect the vested rights of individuals, or societies. . . But the question here is, in whom the property in question is vested? I may be mistaken in my application and inference, but I bow implicitly to the principle. I apprehend, however, that this position respecting the inviolability of vested rights, only extends to such private and perfect rights, as are not hostile to the principles of the government: such as are unconnected with, and depend not upon, the existence of the government. Such rights, or emoluments, as are inseparably connected with, and depend upon the government, must stand or fall therewith. ${ }^{310}$

In short, Roane would not deny the people's power "to reform the government" 311 through the political process as long as the people did not thereby interfere with any "vested right." 312

309. $10 \mathrm{Va} .(6 \mathrm{Call})$ at 156.

310. $10 \mathrm{Va}$. (6 Call) at $169-70$ (emphasis original).

311. $10 \mathrm{Va}$. (6 Call) at 170 .

312. 10 Va. (6 Call) at 169 (emphasis added). But see Terrett v. Taylor, 13 U.S. (9 Cranch) 41,43 (1815) where the Supreme Court, in an opinion by Justice Story, declared unconstitutional the same legislation that had been upheld by the Virginia court in Turpin. According to Story, the Supreme Court was "standing upon the principles of natural justice . . . [and] the fundamental laws of every free government" in holding that the state legislature could not deprive religious corporations of land it had previously granted to them. 13 U.S. (9 Cranch) at 52. This case's special circumstances made this declaration mere dictum, however, and dictum, furthermore, of trivial importance. The case involved glebe lands in Alexandria, which Virginia had ceded to the District of Columbia in 1800, and it came to the Supreme Court on appeal from the circuit court for the ceded district, not from a Virginia state court. Thus, the Virginia Act of 1801, which deprived the church of glebe lands and which was declared unconstitutional by Story, had never applied to the land in Alexandria since that land had been ceded to the federal government prior to the Act. See 13 U.S. (9 Cranch) at 52. The Supreme Court also declared unconstitutional a 1798 Virginia statute which had repealed post-Revolutionary legislation confirming the church's pre-Revolutionary title to the lands in question. That statute's invalidation had no effect on the case's outcome, however, since the church claimed title through pre-Revolutionary grants, which were valid despite the Revolution, the Court held, because "[t]he dissolution of the regal government . . . did not involve in it a dissolution of civil rights, or an abolition of the common law under which the inheritances of every man in the state were held." 13 U.S. $(9$ Cranch) at 50 . The Court also declared it to be 
But, while they would defer to the people's power to reform the law through the political process, state judges, like Marshall and his fellow Supreme Court justices, readily struck down legislation that infringed the vested rights of individuals. For example, in the 1807 Massachusetts case of Ellis $v$. Marshall, ${ }^{113}$ Justice Parker, deciding the constitutionality of an act that taxed an individual for the construction of a road, distinguished between "public act[s], predicated upon a view to the general good," and "private act[s], obtained at the solicitation of individuals, for their private emolument, or for the improvement of their estates." 314 Although he conceded that courts could not interfere with legislative evaluations of the general good, Parker invalidated the tax act because it subjected an individual "to taxation, nolens volens, for the promotion of a private enterprize."315 Similarly, in the 1816 New York case of Gardner v. Village of Newburgh, ${ }^{316}$ Chancellor Kent voided not a tax but an uncompensated diversion of Gardner's stream by the village. Without compensation, such a taking of private property for public use was "unjust, and contrary to the first principles of government,"317 principles "admitted by the soundest authorities, and . . . adopted by all temperate and civilized governments." 318 And in a third case, White v. Kendrick, ${ }^{319}$ the Constitutional Court of South Carolina held that an act extending the jurisdiction of justices of the peace violated one of "the most valuable possessions of the citizen"- the right to trial by jury. ${ }^{320}$

When early nineteenth-century judges refrained from deciding highly controversial questions and merely protected legal rights which few Americans questioned, they were not subjected to political attacks. Thus, the judiciary acted without challenge upon such

\footnotetext{
"a principle of the common law, that the division of an empire creates no forfeiture of previously vested rights of property"-a "principle . . . equally consonant with the common sense of mankind and the maxims of eternal justice." 13 U.S. (9 Cranch) at 50 . Since the Court held that neither the Revolution nor the 1801 Virginia legislation affected the Church's pre-Revolutionary title, its decision of the case did not require finding the 1798 and 1801 Acts unconstitutional. Its dictum was of trivial importance since the Court did not identify any provision of the Constitution which the Virginia legislation impaired and hence failed to provide Virginia litigants with a clear ground on which to appeal to the Supreme Court from state court judgments on the basis of Turpin.
}

313. 2 Mass. 269 (1807).

314. 2 Mass. at 276.

315. 2 Mass. at 277.

316. 2 Johns. Ch. 162 (N.Y. 1816).

317. 2 Johns. Ch. at 168.

318. 2 Johns. Ch. at 166.

319. 3 S.C.L. (1 Brev.) 369 (1805).

320. 3 S.C.L. (1 Brev.) at 369. 
matters as: the composition, ${ }^{321}$ jurisdiction, ${ }^{322}$ and procedure of the courts; ${ }^{323}$ the constitutionality of private acts granting new trials; ${ }^{324}$ the competence of a sheriff to assert his recapture of an escaped debtor as a defense to a creditor's suit against him; ${ }^{325}$ a municipality's power to enact a building code; ${ }^{326}$ and the liability of delinquent clerks for certain statutory penalties. ${ }^{327}$ Only in Ohio did any of these cases lead to controversy, but even in this Ohio affair the practice of judicial review received strong support in the legislature, where a resolution stating that "the courts have the right to judge the constitutionality of our statutes" failed to pass by only one vote and where a committee report declaring that the legislature had "no right to interfere with the court in giving an opinion as to the constitutionality of the law" was accepted by a tie vote. ${ }^{328}$

Of course, the courts were sometimes asked prior to the 1820 s to judge legislation resolving divisive conflicts between political interest groups, but judges generally yielded in those cases to the legislative policy judgment and refused to invalidate the statute before them. The relation of church and state, for example, was a primary cause of political division in Massachusetts and Virginia in the decades around the turn of the century. After a decade of debate, both legislatures moved toward disestablishment, ${ }^{329}$ and, as we have seen, ${ }^{330}$ both state courts deferred to their legislatures. Another political division in many states arose from squatters' improvements upon land wrongfully occupied, ${ }^{331}$ but again, when the Tennessee legislature gave squatters the right to recover for improvements, the Tennessee

321. See, e.g., Cohen v. Hoff, 5 S.C.L. (3 Brev.) 500 (1814).

322. See, e.g., Marbury v. Madison, 5 U.S. (1 Cranch) 137 (1803); Syndics of Brooks v. Weyman, 3 Martin 9 (La. 1813); Whittington v. Polk, 1 H. \& J. 236 (Md. General Ct. 1802); Rutherford v. McFaddon (Ohio Sup. Ct. 1807), reprinted in OHIO UNREPORTED JUDICIAL DECISIONS 71 (E. Pollack ed. 1952); Emerick v. Harris, 1 Binn. 416 (Pa. 1808); White v. Kendrick, 3 S.C.L. (1 Brev.) 469 (1805); Kamper v. Hawkins, 3 Va. (1 Va. Cas.) 20 (1793).

323. See, e.g., Mcllvain v. Holmes, 2 Ky. (Sneed) 317 (1804); Johnson v. Rowland, 2 Ky. (Sneed) 77 (1801); State v. —, 2 N.C. (1 Hayw.) 38 (1794).

324. See, e.g., Hamilton v. Hempsted, 3 Day 332 (Conn. 1809); Holden v. James, 11 Mass. 396 (1814); Merrill v. Sherburne, 1 N.H. 199 (1818). Cf. Dupy v. Wickwire, 1 D. Chip. 237 (Vt. 1814) (act of the legislature which ordered a particular deposition to be read at trial unconstitutional).

325. Dash v. Van Kleeck, 7 Johns. 477 (N.Y. 1811).

326. Respublica v. Duquet, 2 Yeates 493 (Pa. 1799).

327. Caldwell v. Commonwealth, 2 Ky. (Sneed) 129 (1802).

$3 \rightarrow$ Utter, Judicial Review in Early Ohio, 14 Miss. Valley Hist. Rev. 3, 8-9 (1927).

329. P. Goodman, supra note 203, at 162-66; R. BeEman, supra note 199, at 93; see $\mathrm{H}$. Eckenrode, Separation of Church and State in Virginia 74-151 (1910).

330. Adams v. Howe, 14 Mass. 340 (1817); Turpin v. Locket, 10 Va. (6 Call) 113 (1804); see text at notes 304-12 supra.

331. See, e.g., P. Goodman, supra note 203, at 125-27. 
courts accepted the legislative resolution and held the act constitutional. ${ }^{332}$ State courts also upheld a Georgia act postponing debt collection suits ${ }^{333}$ and a Pennsylvania act regulating the militia. ${ }^{334}$ In short, state judges, like Marshall, usually deferred to legislative judgments on matters of policy and protected only those legal rights whose substance few Americans questioned.

\section{E. The Pattern of Early Constitutionalism}

In restricting judicial review to cases in which statutes could be invalidated on the basis of a widely shared consensus about free men's immutable rights, early nineteenth-century courts acted in a style reminiscent of the eighteenth century. Aware that they lacked the power to coerce acceptance of their judgments, Marshall and his contemporaries on the bench rarely attempted to impose the views of one segment of society upon another. When society had become so polarized that shared values could no longer resolve a particular issue, Marshall and his fellow judges simply left the problem to the legislature and the executive, which had the capacity courts lacked to engage in extended public disputation, to identify majority preferences, and to impose those preferences on the minority. The courts, then, resolved only those issues which could be decided with little public disputation-"legal" issues that turned on broadly shared norms. Like their eighteenth-century predecessors, Marshall and other early nineteenth-century judges had only the power to articulate and reason from consensual premises, and they restrained themselves accordingly.

A persistent pattern typified by Marbury $v$. Madison emerges as one surveys the early nineteenth-century cases of judicial review. Whereas the modern Supreme Court, in cases from United States $v$. Butler ${ }^{335}$ to Brown v. Board of Education, ${ }^{336}$ has generally invalidated federal and state legislation having substantial political significance, state and federal courts in the early nineteenth century, as a general rule, invalidated only legislation having almost no political significance. In the few highly controversial cases like $M c C u l l o c h v$. Maryland ${ }^{337}$ in which the Marshall Court did invalidate state statutes, it did so to validate policies already adopted by large majorities

332. Bristoe v. Evans, 2 Tenn. (1 Overt.) 341, 346-47 (1815).

333. Grimball v. Ross, T. Charlt. 175 (Ga. Super. Ct. 1808).

334. Moore v. Huston, 3 Serg. \& Rawl. 169 (Pa. 1817).

335. 297 U.S. 1 (1936).

336. 347 U.S. 483 (1954).

337. 17 U.S. (4 Wheat.) 316 (1819). 
of the Congress rather than to establish a policy of its own. Although our judges cannot do so, early nineteenth-century judges felt able to distinguish law from politics and thereby to extricate themselves from the political thicket.

One can posit at least two reasons for their success. First, the line between law and politics was vitally important to the judges who had drawn it, and they claimed particular matters for the legal side of the line with corresponding modesty. If they had not invariably abstained from deciding arguably political questions, their attempt to enforce received legal principles would have seemed political, not legal, and would have failed. To conserve law's command over some spheres of social life, the judges had to concede law's irrelevance in others.

Second, the judges succeeded because the issue of judicial review arose in a transitional period of American history, when some governmental processes had become political but others had not. Political divisions had become sufficiently deep so that some legislation aroused great controversy, but inherited moral values had not completely broken down, and even the most radical advocates of legislative law-making were unprepared to abandon the still commonly shared belief that law should insulate certain matters-especially the rights of individuals - from the political power of the community. Jefferson and his moderate followers believed in the sanctity of private rights as much as Marshall and the moderate Federalists. The Jeffersonian program had never included any legislative or executive assault upon private legal rights, ${ }^{338}$ and almost no Jeffersonians objected to judicial protection of those rights. As Jefferson himself announced in his first inaugural address, his object was "a wise and frugal Government, which shall restrain men from injuring one another, [and which] shall leave them otherwise free to regulate their own pursuits of industry and improvement"; ${ }^{339}$ as President, Jefferson hoped to pursue "[a] noiseless course, not meddling with the affairs of others." ${ }^{340}$ Accordingly, the appeal by Marshall and other judges to law as the protector of private rights fell upon receptive ears, and their proposed separation of law from politics was initially accepted as a fundamental doctrine of American constitutional law.

In 1809, James Madison ascended to the presidency, and Mar-

338. See R. Ellis, supra note 17, at 30-35.

339. Thomas Jefferson, First Inaugural Address, reprinted in 1 A CoMPILATION OF THE Messages AND PAPERs of The Presidents, 1789-1897, at 323 (J. Richardson ed. 1898).

340. Letter from Thomas Jefferson to Thomas Cooper (Nov. 29, 1802), quoted in R. Ellis, supra note 17 , at 71 . 
shall's goal of preserving the law from the intrusions of politics came within reach. At the very outset of his presidency, Madison mobilized federal force to execute the Supreme Court's judgment in United States v. Peters ${ }^{341}$ after Pennsylvania's Republican governor had called out the militia to prevent it. ${ }^{342}$ Likewise, Congress appropriated funds several years later to enforce the Court's mandate in Fletcher v. Peck. ${ }^{343}$ After 1809, in short, the Marshall Court gained support from Republicans in both the executive and the legislative branches and thus was free to pursue its work in a nonpartisan manner in its newly delimited legal sphere.

Marshall's accomplishment, however, proved only temporary. The era of majoritarian democracy ushered in by Andrew Jackson's presidency unequivocally signalled the end of whatever legal consensus had existed. The Marshall Court received intimations of collapse perhaps as early as 1823 when a storm of protest $^{344}$ vindicated Justice Washington's suspicion that "a great diversity of opinion prevail[ed]" 345 about the issues in Green v. Biddle. ${ }^{346}$ By 1827, Marshall's traditional appeal to natural rights failed to command a majority of the Court in Ogden v. Saunders, ${ }^{347}$ and several years later Georgia refused to obey the Court's mandate in the Cherokee removal cases. ${ }^{348}$ For state judges, consensus also began to disintegrate as early as 1823, when the Kentucky Court of Appeals struck down debtor relief legislation ${ }^{349}$ and was thereupon abolished by the legislature. The abolition of the court produced two years of nationally prominent political strife between advocates of the old court, which refused to accept its own abolition, and advocates of the new, which the legislature had established in the old court's place. ${ }^{350}$

For some, the collapse of consensus was a reason for abandoning

341. 9 U.S. (5 Cranch) 115 (1809).

342. See 4 A. BEVERIDGE, supra note 14, at 18-21; 1 C. WARREN, supra note 11 , at 374-87.

343. 10 U.S. (6 Cranch) 87 (1810).

344. See 4 A. BEVERIDGE, supra note 14, at 374-82, who examines proposals introduced in Congress to repeal $\S 25$ of the Judiciary Act of 1789,1 Stat. 73 , which gave the Supreme Court power to review state judgments, to increase the size of the Court, and to require special majorities to invalidate legislation. There were also resolutions in the state legislature to "call forth the physical power of the state, to resist the execution of the decisions of the court." 29 Niles Weekly Register 228, 229, quoted in A. BeVERIDGE, supra note 14, at 382.

345. Green v. Biddle, 21 U.S. (8 Wheat.) 1, 93 (1823).

346. 21 U.S. (8 Wheat.) 1 (1823).

347. 25 U.S. (12 Wheat.) 213 (1827).

348. See 2 C. WARREN, supra note 11 , at 205-29.

349. See Lapsley v. Brashears, 14 Ky. (4 Litt.) 47 (1823); Blair v. Williams, 14 Ky. (4 Litt.) 34 (1823). 1907).

350. See DuRelle, John Boyle, in 2 Great AMERICAN LAwyers 248-58 (W. Lewis ed. 
judicial review. Pennsylvania's John Banister Gibson, for example, recited the arguments against judicial review in his 1825 dissenting opinion in Eakin v. Raub. ${ }^{351}$ He noted that "[r]epugnance to the constitution is not always self-evident" and that since men "seldom ... think exactly alike," "conflicts" in interpreting constitutional provisions would be "inevitable." 352 If the judiciary once began to consider unconstitutionality, he wondered, "where shall it stop." 353 Gibson discerned no clear lines particularly since reviewing legislation's constitutionality required courts to make what he labelled "political," not "civil" or legal determinations. ${ }^{354}$ Further, he argued that the legislature had "pre-eminence" in government: "the power to legislate" is "the power of the people, and sovereign as far as it extends." 355 Gibson could see no basis for courts to question political decisions made by the people; for him, judicial review denied "a postulate in the theory of our government, and the very basis of the superstructure, that the people are wise, virtuous, and competent to manage their own affairs." 356

Ultimately, of course, Gibson's views have been rejected, and judicial review has become a cornerstone of American constitutionalism. With the rise of majoritarian democracy, however, and with the corresponding collapse of consensus, the courts now practice judicial review under conditions quite different from those in which it may have originated.

\section{CONCLUSION}

How does this essay's interpretation of John Marshall's constitutional jurisprudence square with the older interpretations of Marshall as a principled adjudicator, a politically motivated nationalist, or a servant of the interests of privileged elites?

This essay does not deny the principled quality of Marshall's constitutional jurisprudence. Although I doubt that Marshall found in the intentions of the framers constitutional principles that dictated particular results and although I am uncertain whether his decisions yielded principles that specified future results, this essay's thesis precludes neither possibility. Marshall would not have undercut his efforts to maintain a legal consensus if he had decided cases on the

351. 12 Serg. \& Rawl. 330, 344 (Pa. 1825).

352. 12 Serg. \& Rawl. at 350-51.

353. 12 Serg. \& Rawl. at 349.

354. 12 Serg. \& Rawl. at 346.

355. 12 Serg. \& Rawl. at $347,351$.

356. 12 Serg. \& Rawl. at 355 (emphasis original). 
basis of principles written into the Constitution's text. It is also possible to imagine how his elaboration of an existing consensus might have produced principles that would influence subsequent decisions.

Two limited aspects of Marshall's nationalism also cannot be gainsaid. First, Marshall consistently denied that states could prevent the enforcement of federal court judgments. Second, if federal and state legislation actually or potentially conflicted in their resolution of political questions, Marshall always deferred to Congress rather than the state legislature. ${ }^{357}$

These limited expressions of nationalism were entirely consistent with and perhaps even compelled by Marshall's jurisprudential premise that the courts should only consider issues resolvable by consensual values and should remit other issues to the political process. That premise required that court judgments based on widely accepted constitutional precepts be enforced despite the recalcitrance of individual states. At the same time, however, that premise afforded Marshall little guidance for second-guessing policy judgments-like establishing the Second Bank-made by Congress after years of intense political debate. It also gave Marshall little opportunity in cases like Gibbons and Sturges to delineate the precise scope of constitutional provisions like the commerce and bankruptcy clauses. In those cases, in short, Marshall's jurisprudential premises barred him from limiting Congress' power to legislate within the ambiguous penumbrae of major federal powers, while the supremacy clause provided at least some authority for constraining state power. Hence it is not surprising that Marshall required states to respect federal legislation and widely valued individual rights, but that he otherwise formulated no definitive constitutional rules, leaving the

357. Although Marshall may appear to have occasionally stretched the meaning of federal or state legislation to create a conflict and an opportunity to uphold national power, see Brown v. Maryland, 25 U.S. (12 Wheat.) 419 (1827); Gibbons v. Ogden, 22 U.S. (9 Wheat.) 1 (1824), he did not consistently read congressional legislation broadly to enhance national power. Two notable examples of his restraint are United States v. Hudson \& Goodwin, 11 U.S. (7 Cranch) 32 (1812), and Sturges v. Crowninshield, 17 U.S. (4 Wheat.) 122 (1819). In Hudson, Marshall could have read $\S 11$ of the Judiciary Act, ch. 20, $\S 11,1$ Stat. 78 (1789), which gave circuit courts jurisdiction over crimes committed against the United States, to confer federal common-law jurisdiction by implication, as Justice Story did two years later in United States v. Coolidge, 25 F. Cas. 619 (C.C.D. Mass. 1813) (No. 14,857). Marshall declined to read the section that way, however. Likewise, in Sturges he explicitly declined to hold that expired federal bankruptcy laws extinguished state power over the field; instead, he concluded that Congress' legislation had merely suspended state power which had subsequently revived when the federal act lapsed. See 17 U.S. (4 Wheat.) at 196. That Marshall's decision in Gibbons voided a monopoly and his decision in Brown v. Maryland invalidated a tax, while Sturges upheld popular debtor relief laws and Hudson condemned a politically unpopular federal common law of crimes, suggests that Marshall may have construed legislation with an eye to public opinion. However, the subject of Marshall's legislative construction requires full analysis on another occasion. 
political process, ultimately under Congress' guidance, to set the precise boundaries of national authority.

Even if one accepts Beveridge's or Frankfurter's more expansive view of Marshall's nationalism, this essay's thesis offers useful insight into how that nationalism was cabined. The theory that Marshall's personal qualities enabled him to restrain his political tendencies does not explain the similar restraint of many state judges, whereas this essay's suggestion that early nineteenth-century judges recognized the danger of deciding controversial political questions other than by broadly accepted norms does explain why most judges, including Marshall, restrained themselves. When they heeded the political realities of their time, nearly all judges saw, as the Marshall Court saw in United States v. Hudson \& Goodwin, that they could not read personal preferences into constitutional law when contrary rules had "been long since settled in public opinion" and by "the general acquiescence of legal men." 358

In sum, if one understands Marshall as a nationalist, one should at least also understand him as a nationalist unwilling to undermine existing consensus. Once Marshall's nationalism is so understood, the historical interpretations that emphasize his nationalism no longer sharply conflict with this essay; to view Marshall as a nationalist constrained by consensus differs little from viewing him as a consensus builder who preferred national to local resolution of conflict when there was no consensus.

The thesis of this essay that Marshall embodied in constitutional principle only widely accepted values cannot be as easily reconciled, however, with the claim that he consciously served privileged elites at the expense of other groups. Governing by consensus might have had the ultimate effect of benefitting some groups more than others, but it is difficult to understand how a judge could simultaneously see himself as the advocate of a single group and the protector of the entire society. 359 Where the interests of groups clash, in cases like Sturges v. Crowninshield, a judge like Marshall who is aware of the clash has few choices. He can explicitly favor one group rather than another. He can allow another institution to resolve the conflict. Or he can attempt to decide the issue on principled grounds that transcend any one group's interests. A judge cannot do all three things,

358. 11 U.S. (7 Cranch) 32, 32 (1812).

359. Even a judge who believes that furthering the interests of a particular group benefits the entire society is likely to have a greater ultimate allegiance to one rather than the other and will have to display that allegiance whenever the interests of the group and the society are not plainly consistent. 
however, with a single issue. He must favor one group, favor whatever groups control the political process, or favor no group at all.

This essay has argued that Marshall resolved issues without favoring any group if he could find a commonly shared premise on which to do so and that otherwise he would defer to legislative judgments. This interpretation explains why early nineteenth-century judges sometimes protected vested interests but at other times did not, and it does so without introducing imprecise qualifications which interpretations emphasizing Marshall's elitism require. This is the same advantage that viewing Marshall as a nationalist constrained by consensus has over viewing him as a nationalist constrained by personal traits labelled empiricism and pragmatism.

The greater consistency and precision of this new interpretation does not, however, necessarily make it true. Some readers, I am sure, will not find entirely credible Part I's portrait of eighteenthcentury government by consensus. Concededly, I am insufficiently expert about the details of eighteenth-century American life to assert confidently that there was a widespread moral consensus at the time. Indeed, the knowledge of the entire historical profession may not warrant definitive assertions on that subject. Even my conclusion that eighteenth-century American juries could determine law as well as fact cannot be proved, for yet-unexamined archival material could refute it. I do believe that substantial evidence supports this tentative conclusion and that historians are not likely to discover massive evidence that will destroy it, but new evidence might allow me to state my generalizations about juries and hence about eighteenthcentury government more qualifiedly and precisely than is now possible. Indeed, I hope that this essay sufficiently suggests the importance of the question of jury power that more historians will join the few who so far have searched eighteenth- and early nineteenth-century judicial archives for answers.

Even if eighteenth-century Americans often governed by consensus, as Part I argued, there is no way of knowing whether John Marshall and his contemporaries thought about judicial review in the context of that society or in the context of emerging nineteenth-century class divisions. The historian's only certain conclusion about Marshall and the origins of judicial review is that Marshall may have been a conservator of consensus or that he may have championed, with a restraint we can only roughly estimate, the interests of emerging elites. Unfortunately, the key evidence about the inner workings of his mind evades our reach. 
Why, then, a new interpretation? First, while it cannot be proved true, its elaboration questions the received wisdom that Marshall and his contemporaries imbued constitutional doctrine with Federalist political principles. Perhaps Marshall's objectives on the bench were highly political, but it is also possible to perceive Marshall as having sought to resolve the great political issue of his time-whether popular will or fixed principle should be the source of law-by recourse to a nonpolitical governance technique drawn from an earlier time: the appeal to consensus.

Second, this new interpretation of Marshall's judicial goals may stimulate thought about how the judicial process has functioned and ought to function. For better or for worse, the traditional wisdom about early American constitutionalism has shaped the public's view of courts, particularly its view of the Supreme Court, since at least the 1930s. It has also inspired outstanding historical scholarship, the work of Edward Corwin being but one example. Finally, the received wisdom has led scholars such as Alexander Bickel to analyze in depth how nonpolitical institutional devices can restrain judges' political tendencies. The new interpretation of Marshall and his contemporaries likewise suggests new topics for historical research and a new public conception of the courts' role in constitutional cases. In addition, the new interpretation suggests that legal and political theorists might, if they wish, analyze the political and nonpolitical aspects of the judicial process not only by examining how institutional practices can limit politically inclined men, but also by defining more precisely what makes politics political and hence what might make law nonpolitical. The failure of Marshall and his contemporaries to mark out a precise line between the domains of law and politics leads me to doubt whether scholars of our time will enjoy greater success in drawing that line. On the other hand, the success of Marshall's generation in keeping core segments of the constitutional process free, at least temporarily, from the intrusions of politics raises a possibility that we, too, might sometimes be able, if we try, to perceive some portions of constitutional law as beyond the pale of political controversy. Perhaps others will find this possibility worthy of pursuit. 